\title{
Cameroonian medicinal plants: pharmacology and derived natural products
}

\author{
Victor Kuete ${ }^{1,2}$ and Thomas Efferth ${ }^{2 *}$ \\ Department of Biochemistry, Faculty of Science, University of Dschang, Dschang, Cameroon \\ 2 Department of Pharmaceutical Biology, Institute of Pharmacy, University of Mainz, Mainz, Germany
}

Edited by:

Leslie Gunatilaka, University of Arizona,

USA

\section{Reviwed by:}

Apollinaire Tsopmo, Carleton

University, Canada

Dhammika Nanayakkara, University of

Mississippi, USA

\section{*Correspondence:}

Thomas Efferth, Department of

Pharmaceutical Biology, Institute of

Pharmacy and Biochemistry, University

of Mainz, Staudinger Weg 5, 55128

Mainz, Germany.

e-mail:efferth@uni-mainz.de
Many developing countries including Cameroon have mortality patterns that reflect high levels of infectious diseases and the risk of death during pregnancy and childbirth, in addition to cancers, cardiovascular diseases and chronic respiratory diseases that account for most deaths in the developed world. Several medicinal plants are used traditionally for their treatment. In this review, plants used in Cameroonian traditional medicine with evidence for the activities of their crude extracts and/or derived products have been discussed. A considerable number of plant extracts and isolated compounds possess significant antimicrobial, anti-parasitic including antimalarial, anti-proliferative, anti-inflammatory, anti-diabetes, and antioxidant effects. Most of the biologically active compounds belong to terpenoids, phenolics, and alkaloids. Terpenoids from Cameroonian plants showed best activities as anti-parasitic, but rather poor antimicrobial effects. The best antimicrobial, anti-proliferative, and antioxidant compounds were phenolics. In conclusion, many medicinal plants traditionally used in Cameroon to treat various ailments displayed good activities in vitro. This explains the endeavor of Cameroonian research institutes in drug discovery from indigenous medicinal plants. However, much work is still to be done to standardize methodologies and to study the mechanisms of action of isolated natural products.

Keywords: medicinal plants, ethnopharmacology, Africa

\section{PUBLIC HEALTH CONCERN AND DISEASES IN CAMEROON}

Health care is a basic service essential in any effort to combat poverty, and is often promoted with public funds in Africa to achieve this aim (Castro-Leal et al., 2000). Nevertheless, curative health spending is not always well targeted to the poorest, representing about $50.5 \%$ of Cameroonian (Edmondson, 2001). Many developing countries including Cameroon have mortality patterns that reflect high levels of infectious diseases and the risk of death during pregnancy and childbirth, in addition to cancers, cardiovascular diseases and chronic respiratory diseases that account for most deaths in the developed world (WHO, 2009). In Cameroon, 3 out of 20 patients are able to buy prescribed drugs in hospitals and one out of every 1000 patients are able to see a specialist. Health care activities are coordinated by the Ministry of Public Health which receives the second highest budgetary allocation per ministry each year (Speak Clear Association of Cameroon, 2004). Health facilities are either run as government services or private services managed by the various churches and other private individuals. There are also traditional doctors that play a great role as far as the provisions of health care services are concerned. The major diseases associated with high degree of risk within the population include food or waterborne diseases (bacterial and protozoal diarrhea, hepatitis A and $\mathrm{E}$, and typhoid fever), vector borne diseases (malaria and yellow fever), water contact diseases (schistosomiasis), respiratory diseases (meningococcal meningitis), and animal contact diseases (rabies) (Index mundi, 2008). Very often, there is a coexistence of many infectious diseases. Ammah et al. (1999) demonstrated that high proportion of patients $(33 \%)$ had malaria coexisting with typhoid (Salmonella typhimurium, Salmonella paratyphi, and Salmonella typhi infections). In the Cameroonian population, the lifetime risk of developing active tuberculosis once infected, in absence of HIV infection, is about $10 \%$, meanwhile this increases tenfold in HIV infected individuals (Noeske et al., 2004). Malaria remains the leading cause of morbidity in Cameroon, and among the top five causes of mortality. Malaria represents approximately $45-50 \%$ of health consultations, and 23\% of admissions (Edmondson, 2001). The unsatisfactory management of all diseases throughout the continent as well as in Cameroon, which allows partially treated and relapsed patients to become sequentially resistant, may play a significant role in the development of resistance for infectious diseases (Jones et al., 2008; McGaw et al., 2008). Effective treatment of diseases is challenging for various reasons, including lack of accessibility and elevated expense of drugs and low adherence owing to toxicity of second-line drugs. It is all too likely that the emergence of resistance will be experienced in the future, exhausting the current arsenal of chemical defenses at our disposal. For this purpose, new drugs are urgently needed, and research programs into alternative therapeutics including medicinal plants investigations should be encouraged.

\section{BIODIVERSITY AND PROTECTED AREA IN CAMEROON}

The biodiversity of Cameroon in term of protected land area, number of plant and some animals groups with threatened species are summarized in Table 1 and Figure 1.

Cameroon has a rich biodiversity, with about 8,620 plants species and several animal groups (EarthTrends, 2003), encountered in both protected (about $8 \%$ ), and unprotected areas. About 155 plant species are classified by the International Union for the Conservation 
Table 1 | Biodiversity and protected area in Cameroon, Sub-Saharan Africa, and the World (Source: EarthTrends, 2003).

\begin{tabular}{|c|c|c|c|}
\hline & Cameroon & $\begin{array}{l}\text { Sub-Saharan } \\
\text { Africa }\end{array}$ & World \\
\hline Total land areas & 47,544 & $2,429,241$ & $13,328,979$ \\
\hline \multicolumn{4}{|c|}{ PROTECTED AREA (000 HA) } \\
\hline \multicolumn{4}{|c|}{ Extent of protected areas by IUCN Category (000 ha), 2003} \\
\hline $\begin{array}{l}\text { Total protected area } \\
\text { (Categories I-V) }\end{array}$ & 3,741 & 264,390 & $1,457,674$ \\
\hline $\begin{array}{l}\text { Marine and Littoral } \\
\text { protected areas }\end{array}$ & 389 & - & 417,970 \\
\hline $\begin{array}{l}\text { Protected areas as a } \\
\text { percent of total land area }\end{array}$ & $8.0 \%$ & $10.9 \%$ & $10.8 \%$ \\
\hline \multicolumn{4}{|l|}{ Biosphere reserves in 2002} \\
\hline Number of sites & 3 & 46 & 408 \\
\hline Total area (000 ha) & 876 & - & 439,000 \\
\hline
\end{tabular}

\begin{tabular}{|c|c|c|c|}
\hline \multicolumn{4}{|c|}{ NUMBER AND STATUS OF SPECIES } \\
\hline \multicolumn{4}{|l|}{ Higher plants } \\
\hline $\begin{array}{l}\text { Total known species } \\
\text { (number) }\end{array}$ & 8,260 & - & - \\
\hline $\begin{array}{l}\text { Number of threatened } \\
\text { species }\end{array}$ & 155 & - & 5,714 \\
\hline \multicolumn{4}{|l|}{ Mammals } \\
\hline $\begin{array}{l}\text { Total known species } \\
\text { (number) }\end{array}$ & 409 & - & - \\
\hline $\begin{array}{l}\text { Number of threatened } \\
\text { species }\end{array}$ & 40 & - & 1,137 \\
\hline \multicolumn{4}{|l|}{ Breeding birds } \\
\hline $\begin{array}{l}\text { Total known species } \\
\text { (number) }\end{array}$ & 165 & - & - \\
\hline $\begin{array}{l}\text { Number of threatened } \\
\text { specie }\end{array}$ & 15 & - & 1,192 \\
\hline \multicolumn{4}{|l|}{ Reptiles } \\
\hline $\begin{array}{l}\text { Number of total } \\
\text { known species }\end{array}$ & 210 & - & - \\
\hline $\begin{array}{l}\text { Number of threatened } \\
\text { species }\end{array}$ & 1 & - & 293 \\
\hline \multicolumn{4}{|l|}{ Amphibians } \\
\hline $\begin{array}{l}\text { Number of total } \\
\text { known species }\end{array}$ & 171 & - & - \\
\hline $\begin{array}{l}\text { Number of threatened } \\
\text { species }\end{array}$ & 1 & - & 157 \\
\hline \multicolumn{4}{|l|}{ Fish } \\
\hline $\begin{array}{l}\text { Number of total } \\
\text { known species }\end{array}$ & 138 & - & - \\
\hline $\begin{array}{l}\text { Number of threatened } \\
\text { species }\end{array}$ & 27 & - & 742 \\
\hline
\end{tabular}

IUCN, International Union for the Conservation of Nature and Natural Resources; Categories I, Nature Reserves, Wilderness, Areas; Categories II, National Parks; Category III, Natural monument; Category IV, Habitat/species management area; Category V, Protected landscape/seascape.

"Marine and littoral protected areas are not included in the "Total area protected" above; 'b Includes IUCN categories I-V, marine and littoral protected areas are excluded from these totals.

$(-)$ : data not available. of Nature and Natural Resources (IUCN) as threatened species. Threatened species used as medicinal plants include Thecacoris annobonae Pax \& K. Hoffm (Euphorbiaceae) (Cheek, 2004), Pausinystalia johimbe (K. Schum) (Rubiaceae) (Ngo Mpeck etal., 2004), Prunus africana (Hook. f.) Kalkm (Rosaceae) (Focho et al., 2009). Ancistrocladus korupensis D. W. Thomas \& Gereau (Ancistrocladaceae), Carpolobia lutea G.Don (Polygalaceae), Dacryodes edulis (G. Don) H. J. Lam. (Burseraceae), Enantia chlorantha Oliv (Annonaceae), Garcinia mannii Oliv. (Clusiaceae), Garcinia cola Heckel (Clusiaceae), Gnetum africanum Welw. (Gnetaceae), Invingia gabonensis Baill. (Irvingiaceae), Massularia acuminata (G. Don) Bullock (Rubiaceae), Pentaclethra macrophylla Benth. (Leguminosae), Baillonella toxisperma Pierre var. obovata Aubrév. \& Pellegr. (Sapotaceae), Calamus deeratus Mann \& Wendl. (Palmae), Cola acuminata (P.Beauv.) Schoot et Endl. (Sterculiaceae), Eremospatha macrocarpa (Mann \& Wendl.) Wendl. (Palmae), Raphia regalis Becc. (Palmae), Raphia vinifera P.Beauv. (Palmae) and Ricinodendron heudelotti (Baill.) Pierre (Euphorbiaceae) (Koné, 1997). Protected zones include both land (3,741 ha) and marine areas (389 ha) (EarthTrends, 2003).

\section{ETHNOBOTANICAL USES OF MEDICINAL PLANTS IN CAMEROON}

Traditional healing plays an integral role in black African culture as it provides primary health care needs for a large majority (about $80 \%$ ) of the population (WHO, 2002). In Cameroon, there is a rich tradition in the use of herbal medicine for the treatment of several ailments. Unfortunately, the integration of traditional medicine in the health system is not yet effective, due to its disorganization (Nkongmeneck et al., 2007). However, the government strategies of health envisage the organization of traditional medicine in order to provide the main trends for the development and its integration (Anonymous, 2006). Adjanohoun et al. (1996) provided a useful review of the traditional use of medicinal plants in Cameroon, although much work remains to be done regarding the documentation of existing ethnobotanical knowledge. Jiofack et al. (2010) also documented the traditional use of 289 plants species belonging to 89 families against 220 pathologies. Sixty eight percent of the documented plants are used to treat more than twenty important diseases. They are used as decoction, infusion, maceration, powder, powder mixtures, plaster, calcinations, and squeeze in water, boiling, cooking with young cock or sheep meat or groundnut paste, direct eating, juice, fumigation, and sitz bath (Jiofack et al., 2010). The most recurrent diseases or disorders treated are typhoid, male sexual disorders, malaria, gonorrhea, gastritis, rheumatism, fever, dysentery, diarrhea, dermatitis, boils, cough, wounds, syphilis, sterility, sexually transmitted diseases, ovarian cysts, and amoebiasis, with more than two hundred plants being used to cure these diseases or disorders (Jiofack et al., 2010).

\section{INVESTIGATION OF THE PHARMACOLOGICAL POTENTIAL OF MEDICINAL PLANTS OF CAMEROON ANTIMICROBIAL ACTIVITY}

Plants are widely used traditionally for the treatment of microbial infections. A review of the antimicrobial potential of Cameroon medicinal plants (Kuete, 2010a) reported more than 58 species in vitro active extracts or isolated compounds. Cut-off points for activity in term of $\mathrm{IC}_{50}$-values were set to $100 \mu \mathrm{g} / \mathrm{ml}$ for extract and $25 \mu \mathrm{M}$ for compounds 


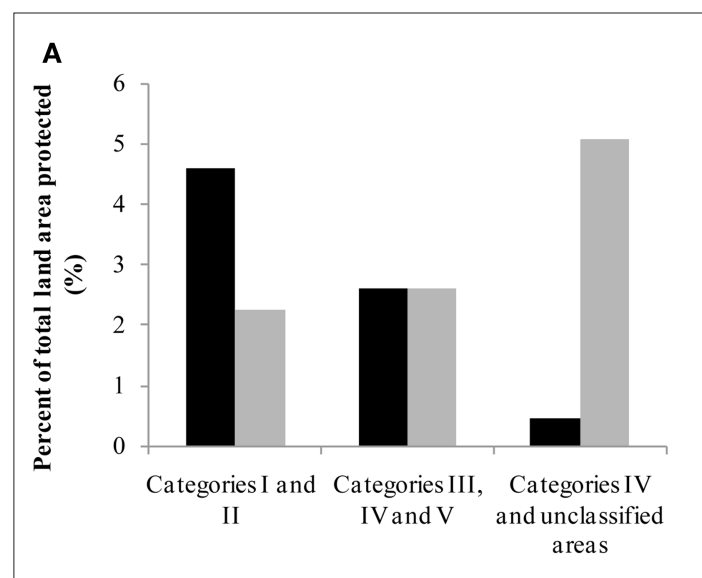

B

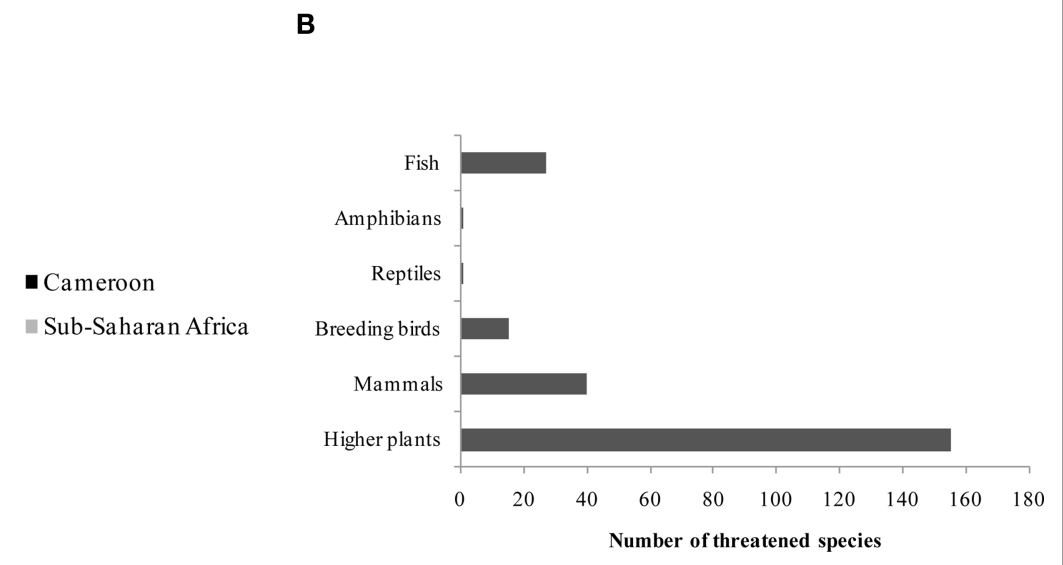

FIGURE 1 | Portion of land area protected (A) by IUCN Category (2003) and threatened species (B) (2002-2003) in Cameroon (Source: EarthTrends, 2003). IUCN, International Union for the Conservation of Nature and Natural Resources; Categories I, nature reserves, wilderness, areas; Categories II, national parks; Category III, natural monument; Category IV, habitat/species management area; Category V, protected landscape/seascape.

(Cos et al., 2006). However, in the case of antimicrobial evaluation of extracts and compounds, determination of $\mathrm{IC}_{50}$ is not the optimal parameter for significance, most of the reported data being given as MIC values. Kuete (2010a) also set the bar as follows for extract: significant $(\mathrm{MIC}<100 \mu \mathrm{g} / \mathrm{ml})$, moderate $(100<\mathrm{CMI} \leq 625 \mu \mathrm{g} / \mathrm{ml})$ or weak $(\mathrm{CMI}>625 \mu \mathrm{g} / \mathrm{ml})$. For compounds, this stringent endpoints criteria were: significant $(\mathrm{MIC}<10 \mu \mathrm{g} / \mathrm{ml})$, moderate $(10<\mathrm{MIC} \leq 100 \mu \mathrm{g} / \mathrm{ml})$, and low or negligible (MIC > $100 \mu \mathrm{g} / \mathrm{ml}$ ) (Kuete, 2010a). More than 50 microorganisms were found to be sensitive to such extracts and significant activity with minimally inhibiting concentrations (MIC) of less than $100 \mu \mathrm{g} / \mathrm{ml}$ (Kuete, 2010a). Some of the extracts including those from Bersama engleriana, Dorstenia angusticornis, Dorstenia barteri, Diospyros canaliculata, Diospyros crassiflora, Newbouldia laevis, and Ficus cordata exhibited a wide range of activity on both bacteria and fungi (Kuete, 2010a).

Some of the bioactive compounds such as diospyrone (23), crassiflorone (24), newbouldiaquinone (25), newbouldiaquinone A (26), laurentixanthone A (30), laurentixanthone B (31), smeathxanthone B (32), cheffouxanthone (33), bangangxanthone A (34), globulixanthone C (35), D (36) and E (37), moracin T (43), and U (44), nkolbisine (59), norerythrosuaveolide (60), were isolated and characterized for the first time from Cameroonian medicinal plants (Kuete, 2010a). Other compounds such as plumbagin (27), lapachol (28) (found to be inactive in vivo in some cases), isobavachalcone (47), 4-hydroxylonchocarpin (48), kanzonol C (49) exhibited interesting activities and were suggested as potential candidates for new antimicrobial drug (Kuete, 2010a). Though compound 28 is known to possess good antimicrobial activity in vitro, it will be necessary to assess its in vivo efficacy. However this compounds was active in vitro against intracellular amastigotes of Leishmania braziliensis and inactive in vivo using hamster infected model (Lima et al., 2004). Thecacoris cf. annobonae Pax \& K. Hoffm (Euphorbiaceae) exhibited significant antimicrobial ( $\mathrm{MIC}<10 \mu \mathrm{g} / \mathrm{ml}$ ) activities against Mycobacterium tuberculosis $\mathrm{H} 37 \mathrm{Rv}$, Bacillus cereus and Pseudomonas aeruginosa (Kuete et al., 2010b). The extract from T. annobonae was reported to induce E. coli death through the inhibition of $\mathrm{H}^{+}$-ATPase-mediated proton pumping (Kuete et al., $2010 \mathrm{~b}$ ). Investigations the mode of resistance of the microorganisms to bioactive compounds isolated from Cameroonian medicinal plants have shown that efflux by AcrAB-TolC pumps was one of the likely mechanisms of defense of Gram-negative bacteria to compounds 23 and 47 (Kuete et al., 2010c).

\section{ANTIMALARIAL ACTIVITY}

In Cameroon, several plant species are used to treat malaria. A review on traditionally used plants reported up to 217 species (Titanji et al., 2008). Some of these plants were screened in vitro for their activity against $P$. falciparum and more than 100 bioactive compounds were isolated (Titanji et al., 2008), most of which, however, showed only low or modest antimalarial activities. In the present review, we focus only on plant extract and compounds that exhibited considerably high activities. The proposed cut-off points for in vitro activity of antimalarial extracts based on their $\mathrm{IC}_{50}$ values can be categorized as follows: $\mathrm{IC}_{50}<0.1 \mu \mathrm{g} / \mathrm{ml}$ (very good); 0.1-1 $\mu \mathrm{g} / \mathrm{ml}$ (good); 1.1-10 $\mu \mathrm{g} /$ $\mathrm{ml}$ (good to moderate); 11-25 $\mu \mathrm{g} / \mathrm{ml}$ (weak), 26-50 (very weak), $>100 \mu \mathrm{g} / \mathrm{ml}$ (inactive) (Willcox et al., 2004a). The following inhibition percentages were proposed for in vivo activity of antimalarial extracts at a fixed dose of $250 \mathrm{mg} / \mathrm{kg} /$ day: $100-90 \%$ (very good activity); $90-50 \%$ (good to moderate); 50-10\% (moderate to weak); 0\% (inactive) (Willcox et al., 2004a). Several plant extracts from Cameroonian medicinal plants were reported for their antimalarial activities (Table 2 ), the most active ( $\mathrm{IC}_{50}<1 \mu \mathrm{g} / \mathrm{ml}$ ) being that from Enantia chlorantha (Boyom et al., 2009).

Some isolated compounds were also reported for their antimalarial activities (Table 2). An $\mathrm{IC}_{50}$ of $1.5 \mu \mathrm{M}$ was chosen as cut-off point for several compounds (Calas et al., 1997). The threshold for in vitro chloroquine resistance has been defined as $\mathrm{IC}_{50}>100 \mathrm{nM}$ (Ringwald et al., 1996). According to Mahmoudi et al. (2006), compounds with $\mathrm{IC}_{50}>5 \mu \mathrm{M}$ were considered as inactive against parasite development, compounds with $\mathrm{IC}_{50}$ between 0.06 and $5 \mu \mathrm{M}$ being active, and values of $\mathrm{IC}_{50}<0.06 \mu \mathrm{M}$ implying the drugs to be very toward $P$. falciparum. We will take into consideration up to $\mathrm{IC}_{50}<20 \mu \mathrm{g} /$ $\mathrm{ml}$ to report on the activity of antimalarial compounds isolated from Cameroonian medicinal plants. So far, active compounds isolated belong to three main groups of secondary metabolites, terpe- 
Table 2 | Plants used in Cameroon to treat malaria, with evidence of their activities.

\begin{tabular}{|c|c|c|c|c|c|}
\hline Family & Species $^{a}$ & Traditional treatment & $\begin{array}{l}\text { Plant part } \\
\text { used }\end{array}$ & $\begin{array}{l}\text { Bioactive (or potentially } \\
\text { active) compounds }\end{array}$ & Screened activity \\
\hline Acanthaceae & $\begin{array}{l}\text { Thomandersia } \\
\text { hensii De Wild } \\
\text { and Th. Dur (LB Th } \\
\text { 0301) }\end{array}$ & $\begin{array}{l}\text { Malaria, diarrhea, colitis, } \\
\text { furuncles, abscesses, } \\
\text { syphilis, ulcers, urogenital } \\
\text { disorders, intestinal parasites, } \\
\text { debility, tiredness, edema, } \\
\text { rheumatism, eye } \\
\text { inflammations (Letouzey, } \\
\text { 1985; Ngadjui et al., 1994). }\end{array}$ & $\begin{array}{l}\text { Bark, leaves, } \\
\text { pulp, sap, } \\
\text { roots }\end{array}$ & Not identified & $\begin{array}{l}\mathrm{IC}_{50}<30 \mu \mathrm{g} / \mathrm{ml} \text { reported for } \\
\text { hexane extract from the stem } \\
\text { bark on } P \text {. falciparum W2 } \\
\text { (Indochina I/CDC) chloroquine- } \\
\text { resistant strain (Bickii et al., } \\
\text { 2007b) }\end{array}$ \\
\hline \multirow[t]{2}{*}{ Annonaceae } & $\begin{array}{l}\text { Uvariopsis } \\
\text { congolana (De } \\
\text { Wild) Fries } \\
\text { (37016/HNC) }\end{array}$ & Malaria (Boyom et al., 2009) & Bark, leaves & $\begin{array}{l}\text { Not identified, but plants of } \\
\text { this family were reported to } \\
\text { contain acetogenins }^{c}\end{array}$ & $\begin{array}{l}\mathrm{IC}_{50}<5 \mu \mathrm{g} / \mathrm{ml} \text { reported for the } \\
\text { crude extract from the leaves and } \\
\text { bark on } P \text {. falciparum strain } \mathrm{W} 2 \\
\text { (Boyom et al., 2009) }\end{array}$ \\
\hline & $\begin{array}{l}\text { Enantia } \\
\text { chlorantha Oliv. } \\
\text { (32065/SRF/Cam) }\end{array}$ & Malaria (Boyom et al., 2009) & Bark, leaves & Not identified & $\begin{array}{l}\mathrm{IC}_{50}<1 \mu \mathrm{g} / \mathrm{ml} \text { reported with the } \\
\text { crude extract from the leaves and } \\
\text { bark on } P \text {. falciparum strain } \mathrm{W} 2 \\
\text { (Boyom et al., 2009) }\end{array}$ \\
\hline Apocynaceae & $\begin{array}{l}\text { Picralima nitida } \\
\text { Stapf (LB Pn } \\
\text { 0301) }\end{array}$ & $\begin{array}{l}\text { Malaria, diarrhoea, intestinal } \\
\text { worms, gonorrhoea, } \\
\text { inflammation (Letouzey, } \\
\text { 1985; Ezeamuzie et al., 1994; } \\
\text { Fakeye et al., 2000) }\end{array}$ & $\begin{array}{l}\text { Bark, roots, } \\
\text { seeds; fruits }\end{array}$ & Not identified & $\begin{array}{l}\mathrm{IC}_{50}<30 \mu \mathrm{g} / \mathrm{ml} \text { reported for the } \\
\text { methanol and dichloromethane- } \\
\text { methanol 1:1 extracts from the } \\
\text { seeds and bark on } P \text {. falciparum } \\
\text { W2 (Indochina I/CDC) chloroquine- } \\
\text { resistant strain (Bickii et al., } \\
\text { 2007b) }\end{array}$ \\
\hline Guttiferae & $\begin{array}{l}\text { Symphonia } \\
\text { globulifera Linn f. } \\
(50788 / \mathrm{HNC})\end{array}$ & $\begin{array}{l}\text { Stomach and skin aches, } \\
\text { laxative for pregnant women, } \\
\text { general tonic, Malaria } \\
\text { (Aubreville, 1950; Irvine, } \\
\text { 1961; Ngouela et al., 2006). }\end{array}$ & Bark & $\begin{array}{l}\text { Gaboxanthone (38); } \\
\text { symphonin (39); globuliferin } \\
\text { (40); guttiferone A (50) } \\
\text { (Ngouela et al., 2006). }\end{array}$ & $\begin{array}{l}\mathrm{IC}_{50}<20 \mu \mathrm{M} \text { on } P \text {. falciparum } \\
\text { reported for compounds } \mathbf{3 8 - 4 0} \\
\text { and } \mathbf{5 0} \text { ( } \text { (Ngouela et al., 2006). }\end{array}$ \\
\hline Lauraceae & $\begin{array}{l}\text { Beilschmiedia } \\
\text { zenkeri Engl. }\end{array}$ & Not reported & Bark & $\begin{array}{l}\text { 5-Hydroxy-7,8- } \\
\text { dimethoxyflavone; } \\
\text { pipyahyine; betulinic acid } \\
\text { (Lenta et al., 2009) }\end{array}$ & $\begin{array}{l}\mathrm{IC}_{50}<5 \mu \mathrm{M} \text { on chloroquine- } \\
\text { resistant } P \text {. falciparum reported for } \\
\text { pipyahyine (Lenta et al., 2009) }\end{array}$ \\
\hline Meliaceae & $\begin{array}{l}\text { Entandrophragma } \\
\text { angolense } \\
\text { Welwitsch C.D.C. } \\
\text { (29933/HNC) }\end{array}$ & Malaria (Bickii et al., 2007a) & Bbark & $\begin{array}{l}\text { 22-Hydroxyhopan-3-one; } \\
\text { 24-methylenecycloartenol } \\
\text { (8); tricosanoic acid; } \\
\text { methylangolensate; } \\
\text { 7 } \alpha \text {-acetoxydihydronomilin } \\
\text { (9); } 7 \alpha \text {-obacunylacetate (10) } \\
\text { (Bickii et al., 2007a) }\end{array}$ & $\begin{array}{l}\mathrm{IC}_{50}<20 \mu \mathrm{g} / \mathrm{ml} \text { on } P \text {. falciparum } \\
\text { W2 strain reported for } \\
\text { compounds } 8-10 \text {. The } \\
\text { dichloromethane }- \text { methanol }(1: 1) \\
\text { extract of the stem bark of that } \\
\text { plant exhibited } \mathrm{IC}_{50} \text { of } 18.8 \mu \mathrm{g} / \mathrm{ml} \\
\text { (Bickii et al., 2007a) }\end{array}$ \\
\hline
\end{tabular}


Table 2 | Continued

\begin{tabular}{|c|c|c|c|c|c|}
\hline Family & Species $^{a}$ & Traditional treatment & $\begin{array}{l}\text { Plant part } \\
\text { used }\end{array}$ & $\begin{array}{l}\text { Bioactive (or potentially } \\
\text { active) compounds }{ }^{b}\end{array}$ & Screened activity \\
\hline & $\begin{array}{l}\text { Khaya } \\
\text { grandifoliola } \\
\text { C.D.C. (PM } \\
\text { 098/95/HNC) }\end{array}$ & $\begin{array}{l}\text { Malaria (Obih et al., 1985; } \\
\text { Bray et al., 1990; Weenen } \\
\text { et al., 1990). }\end{array}$ & $\begin{array}{l}\text { Bark and } \\
\text { seeds }\end{array}$ & $\begin{array}{l}\text { Methylangolensate (1); } \\
\text { 6-methylhydroxyangolensate } \\
\text { (2); gedunin (3); catechin; } \\
\text { 7-deacetylkhivorin (4); } \\
\text { 1-deacetylkhivorin (5); } \\
\text { swietenolide (6); } \\
\text { 6-acetylswietenolide (7) } \\
\text { (Bickii et al., 2000) }\end{array}$ & $\begin{array}{l}\mathrm{IC}_{50}<20 \mu \mathrm{g} / \mathrm{ml} \text { on } P \text {. falciparum } \\
\text { W2 strain reported for bark and } \\
\text { seeds extracts; compounds } \mathbf{1 - 7 .} \\
\text { Compound } \mathbf{3} \text { exhibited an additive } \\
\text { effect when combined with } \\
\text { chloroquine (Bickii et al., 2000) }\end{array}$ \\
\hline & $\begin{array}{l}\text { Turreanthus } \\
\text { africanus }\end{array}$ & $\begin{array}{l}\text { Malaria and other fevers } \\
\text { (Zhou et al., 1997) }\end{array}$ & $\begin{array}{l}\text { Bark, seeds, } \\
\text { leaves }\end{array}$ & $\begin{array}{l}\text { 16-oxolabda-8 (17), } \\
\text { 12(E)-dien-15-oic acid; } \\
\text { methyl-14, 15-epoxylabda-8 } \\
\text { (17), 12(E)-diene-16-oate; } \\
\text { turreanin A (Ngemenya et al., } \\
\text { 2006) }\end{array}$ & $\begin{array}{l}\text { None of the active compounds } \\
\text { exhibited } \mathrm{IC}_{50}<20 \mu \mathrm{g} / \mathrm{ml} \text { on } P \text {. } \\
\text { falciparum } \mathrm{F} 32 \text {, chloroquine } \\
\text { sensitive strain (Ngemenya et al., } \\
\text { 2006) }\end{array}$ \\
\hline \multirow[t]{2}{*}{ Moraceae } & $\begin{array}{l}\text { Artocarpus } \\
\text { communis J.R. \& } \\
\text { G. Forst ( } 43982 \\
\text { HNC) }\end{array}$ & Malaria (Boyom et al., 2009) & Bark, leaves & Not identified & $\begin{array}{l}\mathrm{IC}_{50}<10 \mu \mathrm{g} / \mathrm{ml} \text { reported for the } \\
\text { crude extract from the leaves and } \\
\text { bark on } P \text {. falciparum strain } \mathrm{W} 2 \\
\text { (Boyom et al., 2009) }\end{array}$ \\
\hline & $\begin{array}{l}\text { Dorstenia } \\
\text { convexa De Wild } \\
(53450 \mathrm{HNC})\end{array}$ & Malaria (Boyom et al., 2009) & Twigs & Not identified & $\begin{array}{l}\mathrm{IC}_{50}<10 \mu \mathrm{g} / \mathrm{ml} \text { reported with the } \\
\text { crude extract from the twigs on } P \text {. } \\
\text { falciparum strain W2 (Boyom } \\
\text { et al., 2009) }\end{array}$ \\
\hline \multirow[t]{2}{*}{ Zingiberaceae } & $\begin{array}{l}\text { Aframomum } \\
\text { zambesiacum } \\
\text { (Baker) K. Schum } \\
\text { (37737HNY) }\end{array}$ & $\begin{array}{l}\text { Malaria (Kenmogne et al., } \\
\text { 2006) }\end{array}$ & Seeds & $\begin{array}{l}\text { Aulacocarpin A (11); } \\
\text { aulacocarpin B; } \\
\text { 3-deoxyaulacocarpin A (12); } \\
\text { methyl-14n,15-epoxy-3b- } \\
\text { hydroxy-8(17),12-elabdadien- } \\
\text { 16-oate; galanolactone; } \\
\text { zambesiacolactone A (13); } \\
\text { zambesiacolactone B (14); } \\
\text { aframodial (Kenmogne et al., } \\
\text { 2006) }\end{array}$ & $\begin{array}{l}\mathrm{IC}_{50}<20 \mu \mathrm{M} \text { on } \text { P. falciparum } \\
\text { reported for compounds } \mathbf{1 1 - 1 4} \\
\text { (Kenmogne et al., 2006) }\end{array}$ \\
\hline & $\begin{array}{l}\text { Reneilmia } \\
\text { cincinnata (K. } \\
\text { Schum.) Bak. }\end{array}$ & $\begin{array}{l}\text { Malaria (Tchuendem et al., } \\
\text { 1999) }\end{array}$ & Fruits & 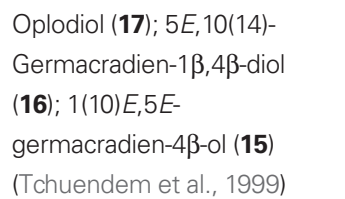 & $\begin{array}{l}\mathrm{IC}_{50}<5 \mu \mathrm{M} \text { reported on } P \\
\text { falciparum D6 and W2 strains for } \\
\text { compounds } \mathbf{1 5 - 1 7} \text { on } P \text {. } \\
\text { falciparum D6 strain (Tchuendem } \\
\text { et al., } 1999\end{array}$ \\
\hline
\end{tabular}

aHC or SRFK: Cameroon National herbarium code; LB, Laboratory of Botany, Yaoundé.

${ }^{b}$ Compounds characterized for the first time in Cameroonian medicinal plant are underlined.

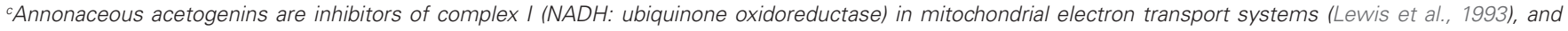
NADH oxidase of plasma membranes (Morré et al., 1995), two enzymes found in Plasmodium falciparum.

noids (Figure 2), phenolics (Figure 3), and alkaloids (Figure 4). Antimalarial terpenoids including sesqui-, di-, and triterpenoids are the most frequently isolated compounds from Cameroonian plants. Several natural products were reported as being active against Plasmodium falciparum, with $\mathrm{IC}_{50}$ values below $20 \mu \mathrm{g} / \mathrm{ml}$, including methylangolensate (1); 6-methylhydroxyangolensate (2); gedunin (3); 7-deacetylkhivorin (4); 1-deacetylkhivorin (5); swietenolide (6); 6-acetylswietenolide (7) (Bickii et al., 2000); 24-methylenecycloartenol (8); $7 \alpha$-acetoxydihydronomilin (9); $7 \alpha$-obacunylacetate (10) (Bickii et al., 2007a); aulacocarpin A (11); 3-deoxyaulacocarpin A
(12); zambesiacolactone A (13), and B (14) (Kenmogne et al., 2006); $1(10) E, 5 E$-germacradien-4 $\beta$-ol (15); 5E,10(14)-germacradien1 $\beta, 4 \beta$-diol (16); oplodiol (17) (Tchuendem et al., 1999); $\mathrm{IC}_{50}<5 \mu \mathrm{g} /$ $\mathrm{ml}$ were obtained for compounds $\mathbf{3}(1.25 \mu \mathrm{g} / \mathrm{ml})$, and $\mathbf{1 0}(2 \mu \mathrm{g} / \mathrm{ml})$ (Bickii et al., 2000, 2007a), while values below $5 \mu \mathrm{M}$ were recorded for compounds $12(4.97 \mu \mathrm{M})$ (Kenmogne et al., 2006), 15 (1.54 $\mu \mathrm{M})$; $16(1.63 \mu \mathrm{M})$ and $17(4.17 \mu \mathrm{M})$ (Tchuendem et al., 1999).

Phenolic compounds (Figure 3) such as gaboxanthone (38); symphonin (39); globuliferin (40); guttiferone A (50) (Ngouela et al., 2006) also exhibited antimalarial activities when tested on 


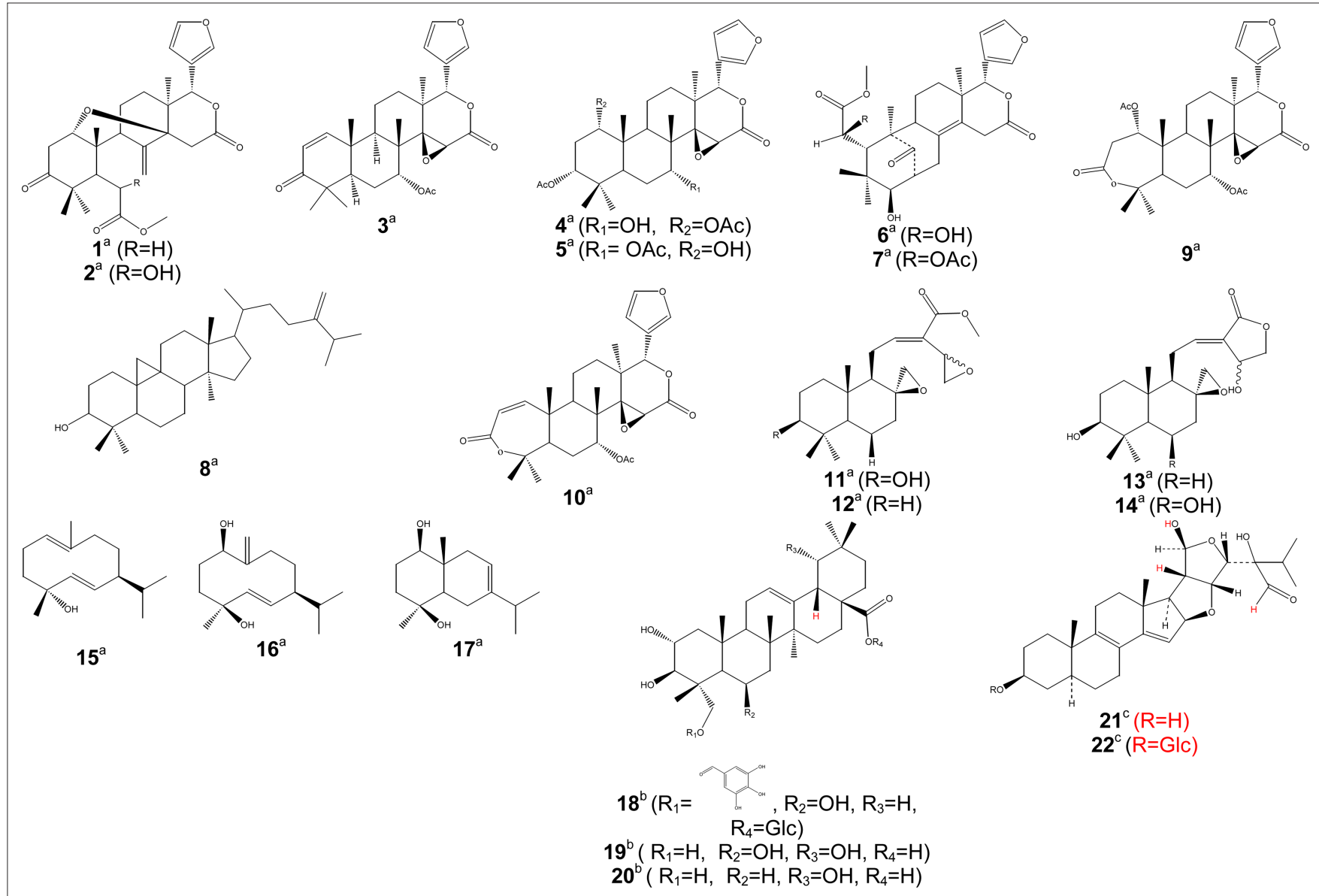

FIGURE 2 | Bioactive terpenoids. Activity [(a) antimalarial, (b) anti-inflammatory, (c) antitrypanosomal]; Glc, glucosyl group; Ac, acetyl group.

P. falciparum. IC $_{50}$ values below $5 \mu \mathrm{g} / \mathrm{ml}$ were reported with compounds $\mathbf{3 8}(3.53 \mu \mathrm{M}) ; \mathbf{3 9}(1.29 \mu \mathrm{M}) ; \mathbf{4 0}(3.86 \mu \mathrm{M})$ and $\mathbf{5 0}(3.17 \mu \mathrm{M})$ (Ngouela et al., 2006). Few alkaloids from Cameroonian medicinal plants (Figure 4) were characterized. For example, pipyahyine (61) exhibited good activity $\left(\mathrm{IC}_{50}<5 \mu \mathrm{M}\right)$ toward chloroquine-resistant P. falciparum (Lenta et al., 2009).

Studies dealing with the mechanisms of action of antimalarial compounds are still limited. However, some of the extracts from Cameroonian medicinal plants such as those from Annonaceae species were suggested to exert their antiplasmodial activity by the inhibition of vital parasitic enzymes such as cysteine proteases (Boyom et al., 2009).

\section{OTHER ANTI-PARASITIC ACTIVITIES}

Parasitic trypanosomatids cause a number of important diseases, including human African trypanosomiasis, Chagas disease, and leishmaniasis. More than 60 million people living in 36 sub-Saharan Africa countries are at risk of contracting sleeping sickness, caused by Trypanosoma brucei gambiense and T. b. rhodesience (WHO, 2007). It is estimated that currently $300,000-500,000$ people were infected in 2001, with 50,000 deaths annually (Fairlamb, 2003; WHO, 2007).Leishmania species cause a spectrum of disease ranging from self-healing cutaneous lesions to life-threatening visceral infections, with 2 million new cases occurring annually (WHO,
2005). It is estimated that about 200 million people worldwide are currently affected by schistosomiasis, a disease caused by flatworms belonging to the genus Schistosoma. The disease is usually chronic and debilitating, with severe consequences on the urinary tract where S. haematobium is the organism involved and major damage to the intestinal tract where S. mansoni, S. intercalatum or $S$. japonicum are involved (Jatsa et al., 2009). In humans, Toxoplasma infections are widespread and lead to severe diseases in individuals with immature or suppressed immune system. Consequently, toxoplasmosis became one of the major opportunistic infections of the AIDS epidemic (Luft and Remington, 1992). Toxoplasmosis also affects T. gondii-negative women during pregnancy and is a serious threat for embryos. Despite the huge impact of these parasitic diseases, the drugs used for their treatment are often toxic, marginally effective, administered by injection only, expensive, and/or compromised by the development of resistance (Ouellette et al., 2004; Croft et al., 2005). Only few researchers in Cameroon focused on antitrypanosomal and antileishmanial compounds from medicinal plants. Available published data on traditionally used medicinal plants are compiled in Table 3. Herein, similar cut-off points as indicated above for antimalarials have been considered for activities against trypanosomal, leishmanial and schistosomal pathogens. Compounds with good antileishmanial activities were isolated from Garcinia lucida (Clusiaceae), with $\mathrm{IC}_{50}$ 


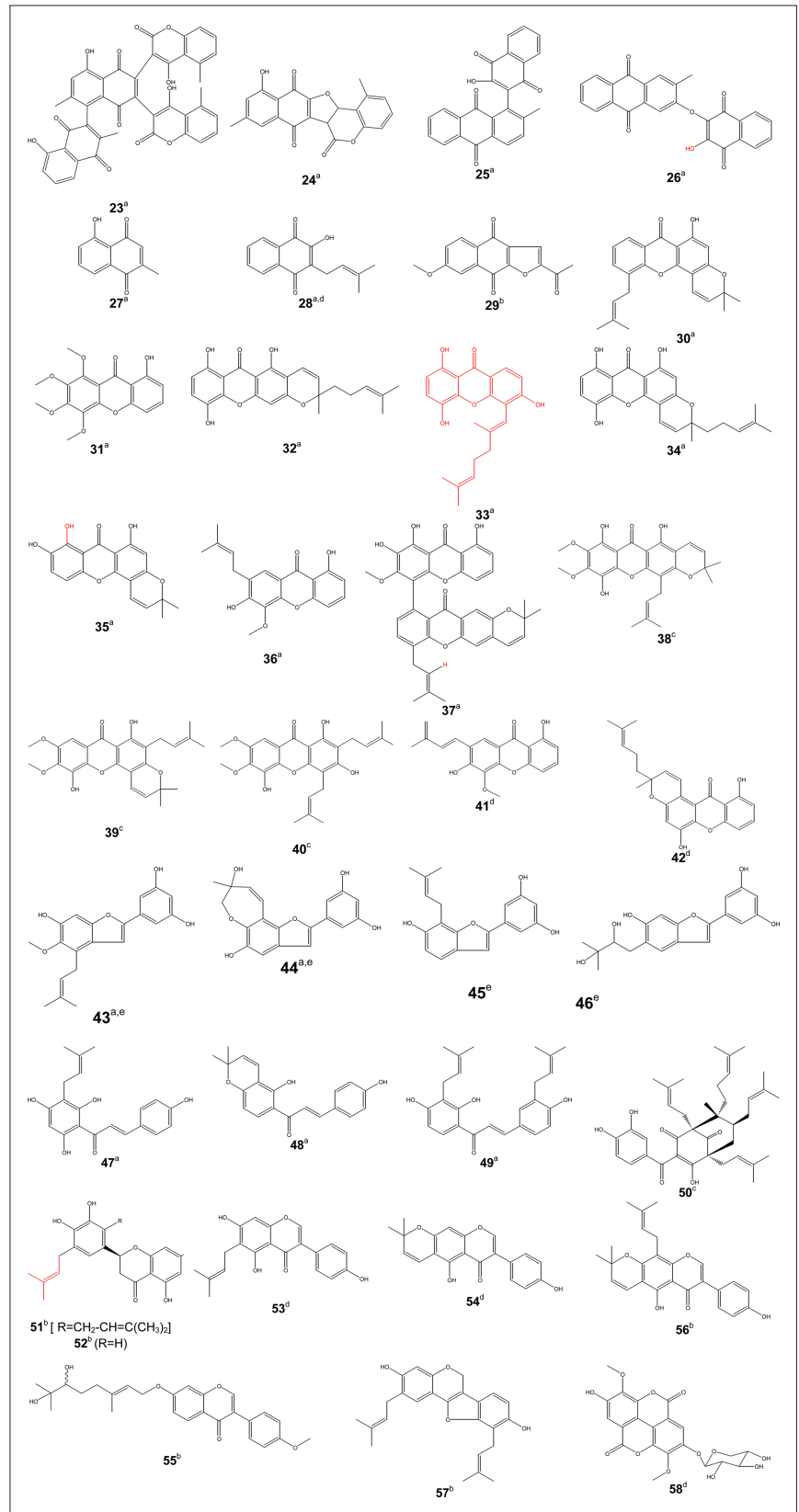

FIGURE 3 | Bioactive phenolics [quinones (23-29), xanthones (30-42), arylbenzofurans (43-46)]. Activity [(a) antimicrobial, (b) anti-inflammatory, (c) antimalarial, (d) anti-proliferative, (e) antioxidant]. [Chalcones (47-49), benzophenone (50), flavone (51-52), isoflavones (53-56), pterocarpene (57), ellagic acid derivative (58)]. Activity [(a) antimicrobial, (b) anti-inflammatory, (c) antimalarial, (d) anti-proliferative, (e) antioxidant].

values of 2.0 and $6.6 \mu \mathrm{g} / \mathrm{ml}$, respectively, for dihydrochelerythrine (62) and 6-acetonyldihydrochelerythrine (63) against L. donovani (Fotie et al., 2007). Significant antitrypanosomal activities were also reported for stigmastane derivatives, vernoguinosterol (21) and vernoguinoside (22) (Figure 2) isolated from Vernonia guineensis (Asteraceae), against bloodstream trypomastigotes of Trypanosoma brucei rhodesiense with $\mathrm{IC}_{50}$ values ranging from 3 to $5 \mu \mathrm{g} / \mathrm{ml}$ (Tchinda et al., 2002).

\section{ANTI-PROLIFERATIVE ACTIVITY}

Screenings of medicinal plants used as anticancer drugs has provided modern medicine with effective cytotoxic pharmaceuticals. More than $60 \%$ of the approved anticancer drugs in United State of America (from 1983 to 1994) were from natural origin (Stévigny et al., 2005; Newman and Cragg, 2007). The diversity of the biosynthetic pathways in plants has provided a variety of lead structures that have been used in drug development. In this last decade, investigations on natural compounds have been particularly successful in the field of anticancer drug research. Early examples of anticancer agents developed from higher plants are the antileukemic alkaloids (vinblastine and vincristine), which were both obtained from the Madagascar periwinkle (Catharanthus roseus) (Voss et al., 2005). The development of the highly automated bioassay screening based on colorimetric methods that quantified the proliferation of cell culture (Mosmann, 1983) of a huge number of plants extracts have permitted to find that many plant families (Guittiferae, Rubiaceae, Apocynaceae, Euphorbiaceae, Solanaceae, etc.) exhibited a great potential of anti-proliferative activity (Hostettmann et al., 2000; Whelan and Ryan, 2003). A large number of plant extracts have shown the in vitro and in vivo antitumor activities (Hostettmann et al., 2000). In the US NCI plant screening program, a crude extract is generally considered to have in vitro cytotoxic activity if the $\mathrm{IC}_{50}$ value following incubation between 48 and $72 \mathrm{~h}$, is less than $20 \mu \mathrm{g} /$ $\mathrm{ml}$, while it is less than $4 \mu \mathrm{g} / \mathrm{ml}$ for pure compounds (Boik, 2001). This cut-off point for good cytotoxic compound has also been defined as $10 \mu \mathrm{M}$ (Brahemi et al., 2010). Despite the exceptional biodiversity of Africa, few scientific studies have been carried out in the continent regarding the anti-proliferative properties of medicinal plants. However, some Cameroonian plants and derived natural products were tested for their anti-proliferative effects. Five medicinal plants widely used in cancer treatment, Sida acuta, Sida cordifolia, Sida rhombilifolia, Urena lobata, Viscum album, were recently screened for their cytoxicity against Hep G2 hepatocarcinoma cells rather showed moderate anti-proliferative effects (Pieme et al., 2010). However, studies based on the inhibition of Crown Gall tumors revealed pronounced tumor reducing activity of extracts from the roots and leaves from Bersama engleriana (Kuete et al., 2008). An $\mathrm{IC}_{50}$ of $27.16 \mu \mathrm{g} / \mathrm{ml}$ was reported for Antiaris africana in DU-145 prostate cancer cells, while even better activity $\left(\mathrm{IC}_{50}\right.$ of $13.84 \mu \mathrm{g} / \mathrm{ml}$ ) was recorded in Hep G2 hepatocarcinoma cells (Kuete et al., 2009). One of the most active compounds isolated from A. africana, 3,39-dimethoxy-49-O- $\beta$-D-xylopyronosylellagic acid (58) (Figure 3) exhibited considerable anti-proliferative activities toward HepG2 $\left(\mathrm{IC}_{50}\right.$ of $\left.3.84 \mu \mathrm{g} / \mathrm{ml}\right)$ and DU-145 $\left(\mathrm{IC}_{50}\right.$ of $6.24 \mu \mathrm{g} /$ $\mathrm{ml}$ ) cells (Kuete et al., 2009). Compound 28, the main constituent of a Cameroonian medicinal plant, Newbouldia leavis (Bignoniaceae) was found to be very active against DU-145 cells with an $\mathrm{IC}_{50}$ of $64.59 \mathrm{nM}$ (Eyong et al., 2008). Wighteone (53) and alpinumisoflavone (54) isolated from Erythrina indica (Leguminosae) were reported to be cytotoxic (effective dose of 0.78 and $4.13 \mu \mathrm{g} / \mathrm{ml}$, respectively) when tested against $\mathrm{KB}$ nasopharyngeal cancer cells (Nkengfack et al., 2001). Globulixanthones A (41) and B (42) isolated for the first time in the Cameroonian medicinal plant, Symphonia globulifera L. f. (Clusiaceae), showed good anti-proliferative activities against human $\mathrm{KB}$ cells, with $\mathrm{IC}_{50}$ values of 2.15 and $1.78 \mu \mathrm{g} / \mathrm{ml}$, respectively (Nkengfack et al., 2002). Compound 


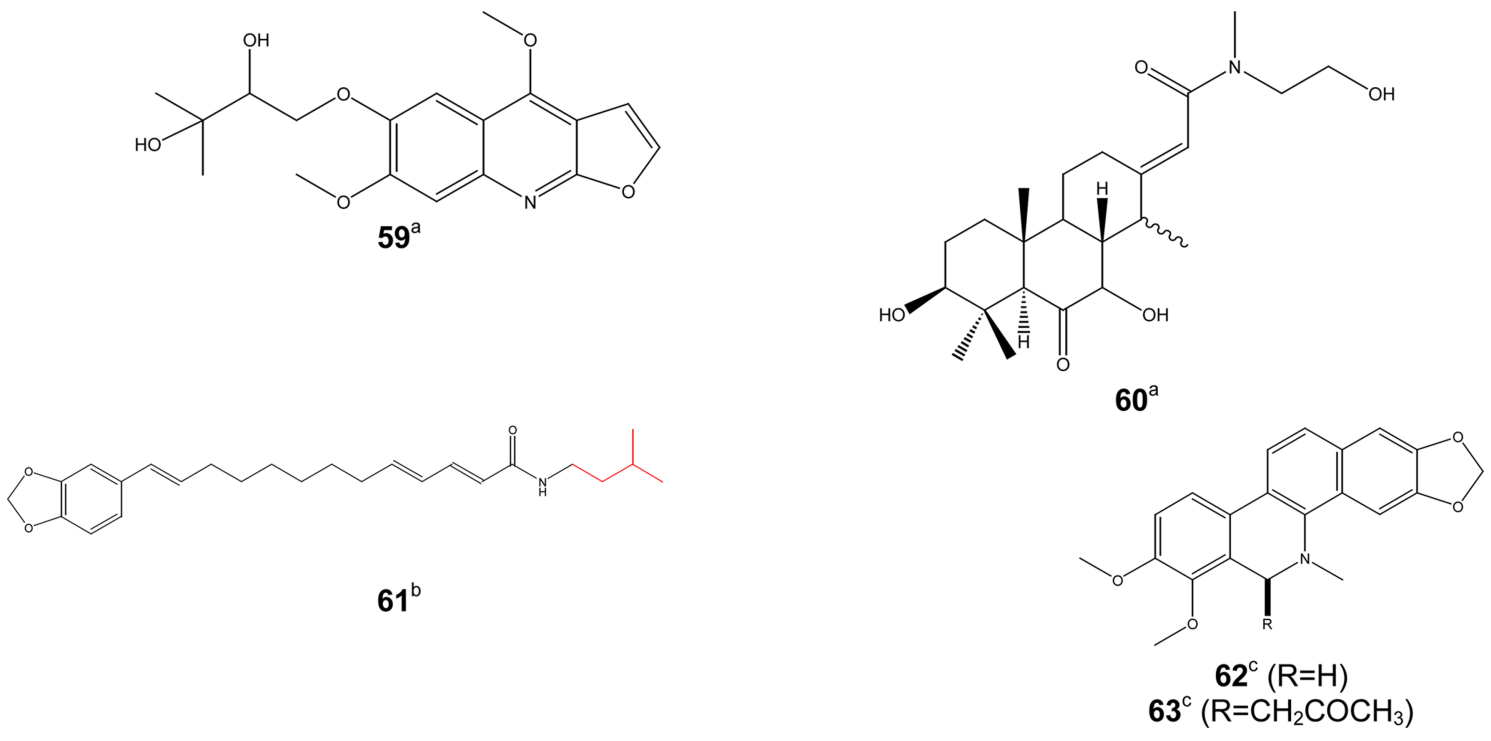

FIGURE 4 | Bioactive alkaloids. Activity [(a) antimicrobial, (b) antimalarial, (c) antileishmanial].

47 isolated from Dorstenia barteri (Ngameni et al., 2007) and D. turbinata (Ngameni et al., 2009) was cytotoxic toward a wide spectrum of tumor cell lines, including ovarian carcinoma OVCAR-8 cells, prostate carcinoma PC3 cells, breast carcinoma MCF-7 cells, and lung carcinoma A549 cells (Jing et al., 2010). Compound 47 significantly ablated Akt phosphorylation at Ser-473 and Akt kinase activity in cells, which subsequently led to inhibition of Akt downstream substrates and evoked significant levels the mitochondrial pathway of apoptosis (Jing et al., 2010). Nishimura et al. (2007) demonstrated that compound 47 induced apoptotic cell death with caspase- 3 and -9 activation and Bax upregulation in neuroblastoma cell lines. Compound 47 inhibited MMP-2 secretion from U87 glioblastoma cells (Ngameni et al., 2007). Compounds 48 and 49 also isolated from Dorstenia turbinata (Moraceae), inhibited the matrix metalloproteinase (MMP)-2 secretion from brain tumorderived glioblastoma cells (Ngameni et al., 2006).

\section{ANTI-INFLAMMATORY AND ANALGESIC ACTIVITIES}

Pain is one common health problem with substantial socioeconomic impact because of its high incidence. It is a symptom of many diseases and it is estimated that $80-100 \%$ of the population experience back pain at least once in the life time (Jain et al., 2002). The treatment of pain requires analgesics including inflammatory products. Hence, most of the non-steroidal anti-inflammatory agents also have analgesic activity. The inhibition of prostaglandin E2 (PGE2) and nitric oxide (NO) production has been proposed as a potential therapy for different inflammatory disorders (Nowakowska, 2007). Although, many analgesics and anti-inflammatory agents are present on the market, modern drug therapy is associated with some adverse effects like gastrointestinal irritation (Jain et al., 2002; Osadebe and Okoye, 2003), fluid retention, bronchospasm, and prolongation of bleeding time. Therefore, it is necessary to search for new drugs with less adverse effects. Medicinal plants have been used for the development of new drugs and continue to play an invaluable role for the progress of drug discovery (Raza et al., 2001). Plant extracts can be an important source of safer drugs for the treatment of pain and inflammation. Several medicinal plants and derived products were screened for their anti-inflammatory and analgesic properties (Table 4). Bark extract as well as terpenoids from Combretum molle (Combretaceae), $\beta$-D-glucopyranosyl $2 \alpha, 3 \beta, 6 \beta$-trihydroxy23-galloylolean-12-en-28-oate (18); combregenin (19); arjungenin (20) (Figure 2) showed good activities against carrageenan-induced paw edema in rat (Ponou et al., 2008). A naphthoquinone, 2-acetyl7-methoxynaphthol[2,3-b]furan-4,9-quinone (29), isolated from the anti-inflammatory crude extract of Millettia versicolor inhibited 12-O-tetradecanoylphorbol 13-acetate (TPA)-induced acute ear edema and phospholipase $\mathrm{A}_{2}\left(\mathrm{PLA}_{2}\right)$ acute mouse paw edema (Fotsing et al., 2003). Isoflavones, griffonianone D (55) (Figure 3) isolated from Millettia griffoniana (Yankep et al., 2003), warangalone (56) isolated from the bark of Erythrina addisoniae (Talla et al., 2003), and erycristagallin (57) isolated from the root of Erythrina mildbraedii (Njamen et al., 2003), showed marked effectiveness as an anti-inflammatory on PLA $_{2}$-induced paw edema and on TPAinduced ear edema in mice (Njamen et al., 2003; Talla et al., 2003). Flavonoids sigmoidin A (51) and B (52) (Figure 3) isolated from Erithrina sigmoidea, and compound $\mathbf{5 7}$ were also effective against TPA-induced ear edema (Njamen et al., 2003, 2004).

\section{ANTI-DIABETIC ACTIVITY}

Diabetes mellitus is a group of metabolic disorders with one common manifestation, hyperglycemia (WHO, 1980, 1985). Chronic hyperglycemia causes damage to eyes, kidneys, nerves, heart, and blood vessels (Mayfield, 1998). It is caused by inherited and/or acquired deficiency in insulin production of the pancreas, or by unresponsiveness toward insulin. It results either from inadequate secretion of hormone insulin, an inadequate response of target cells to insulin, or a combination of these factors (Malviya et al., 2010). Diabetes is projected to become one of the world's main disablers and killers within the next 25 years (Malviya et al., 2010). The management of diabetes is a global problem and a successful treatment 
Table 3 | Plants used in Cameroon to treat some parasitic infections with evidence of their activities.

\begin{tabular}{|c|c|c|c|c|c|}
\hline Family & Species $^{\mathrm{a}}$ & Traditional treatment & $\begin{array}{l}\text { Plant part } \\
\text { used }\end{array}$ & $\begin{array}{l}\text { Bioactive (or potentially } \\
\text { active) compounds }^{b}\end{array}$ & Screened activity ${ }^{c}$ \\
\hline Annonaceae & $\begin{array}{l}\text { Polyalthia } \\
\text { suaveolens Engl. } \\
\text { \& Diels (1227/ } \\
\text { SRFK) }\end{array}$ & $\begin{array}{l}\text { Rheumatic pains (Surville, } \\
\text { 1955) }\end{array}$ & $\begin{array}{l}\text { Not } \\
\text { specified }\end{array}$ & $\begin{array}{l}\text { Polyveoline; 3-O-acetyl } \\
\text { greenwayodendrin; POLYSIN; } \\
\text { greenwayodendrin-3-one } \\
\text { (Ngantchou et al., 2010) }\end{array}$ & $\begin{array}{l}\text { Antitrypanosomal activity: weak } \\
\text { activity for polyveoline }\left(\mathrm{IC}_{50}:\right. \\
32 \mu \mathrm{M}) \text {; } 3 \text {-O-acetyl } \\
\text { greenwayodendrin }\left(\mathrm{IC}_{50}:\right. \\
54 \mu \mathrm{M}) \text {; mixture of polysin and } \\
\text { greenwayodendrin-3-one }\left(\mathrm{IC}_{50}:\right. \\
18 \mu \mathrm{M}) \text { against } T \text {. brucei } \\
\text { (Ngantchou et al., } 2010)\end{array}$ \\
\hline Asteraceae & $\begin{array}{l}\text { Vernonia } \\
\text { guineensis Benth. } \\
\text { (BUD 301) }\end{array}$ & $\begin{array}{l}\text { Anthelmintic, anti-poison, } \\
\text { malaria, jaundice (Iwu, 1993) }\end{array}$ & Leaves & $\begin{array}{l}\text { Vernoguinosterol (21); } \\
\text { vernoguinoside (22) (Tchinda } \\
\text { et al., 2002) }\end{array}$ & $\begin{array}{l}\text { Antitrypanosomal activity: } \\
\text { significant for compounds } \mathbf{2 2} \\
\text { and } \mathbf{2 3} \text { against four strains of } \\
\text { bloodstream trypomastigotes } T \text {. } \\
\text { b. rhodesiense with } \mathrm{IC}_{50} \text { values } \\
\text { in the range } 3-5 \mathrm{mg} / \mathrm{ml} \text { (Tchinda } \\
\text { et al., 2002) }\end{array}$ \\
\hline Guttiferae & $\begin{array}{l}\text { Garcinia lucida } \\
\text { Vesque (5768/ } \\
\text { HNC) }\end{array}$ & $\begin{array}{l}\text { Gastric infections, anti-poison } \\
\text { (Nyemba et al., 1990) }\end{array}$ & Bark & $\begin{array}{l}\text { Dihydrochelerythrine (62); } \\
\text { 6-acetonyldihydrochelerythrine } \\
\text { (63); lucidamine A (Fotie et al., } \\
\text { 2007) }\end{array}$ & $\begin{array}{l}\text { Antileishmanial activity: } \\
\text { Significant activity for } \\
\text { compounds } \mathbf{6 2} \text { and } \mathbf{6 3} \text { and } \\
\text { moderate for lucidamine A } \\
\text { against } L \text {. donovani. Also, } 100 \% \\
\text { Inhibition of promastigote at } \\
100 \mathrm{\mu g} / \mathrm{ml} \text { were reported for all } \\
\text { the above compounds (Fotie } \\
\text { et al., 2007) }\end{array}$ \\
\hline Meliaceae & $\begin{array}{l}\text { Turraeanthus } \\
\text { africanus (Welw. } \\
\text { ex C.D.C.) Pellegr } \\
\text { (8233/HNC) }\end{array}$ & $\begin{array}{l}\text { Asthma, stomachache, } \\
\text { intestinal worms, and } \\
\text { inflammatory diseases } \\
\text { (Ekwalla and Tongo, 2003) }\end{array}$ & $\begin{array}{l}\text { Aerial parts, } \\
\text { roots }\end{array}$ & $\begin{array}{l}\text { Turraeanthin C; sesamin } \\
\text { (Vardamides et al., 2008) }\end{array}$ & $\begin{array}{l}\text { Antitoxoplamal activity: } \\
\text { Moderate activity for } \\
\text { turraeanthin C and low activity } \\
\text { for crude bark extract and } \\
\text { sasamin. Inhibition of parasite } \\
\text { growth at } 10 \mu \mathrm{g} / \mathrm{ml} \text { was found } \\
\text { to be } 55 \% \text { for turraeanthin C, } \\
20 \% \text { for sesamin and } 40 \% \text { for } \\
\text { crude extract (Vardamides et al., } \\
2008 \text { ) }\end{array}$ \\
\hline Verbenaceae & $\begin{array}{l}\text { Clerodendrum } \\
\text { umbellatum Poir } \\
(7405 / \mathrm{HNC})\end{array}$ & $\begin{array}{l}\text { Epilepsy, headache, intestinal } \\
\text { helminthiasis, irregular } \\
\text { menstruation, infective } \\
\text { dermatitis, asthma, } \\
\text { metaphysical powers, } \\
\text { whitlow, vulvovaginitis } \\
\text { (Adjanohoun et al., 1996; Jatsa } \\
\text { et al., 2009) }\end{array}$ & $\begin{array}{l}\text { Not } \\
\text { specified }\end{array}$ & $\begin{array}{l}\text { Not identified but, flavonoids, } \\
\text { saponins, saponosides, } \\
\text { tannins, and triterpenes were } \\
\text { detected in the leaves } \\
\text { aqueous extract (Jatsa et al., } \\
\text { 2009) }\end{array}$ & $\begin{array}{l}\text { Antischistosomal activity: } \\
100 \% \text { reduction rate reported } \\
\text { for mice infected with } S \text {. } \\
\text { mansoni when treated with } \\
160 \text { mg/kg body weight of } \\
\text { aqueous leaves extract (Jatsa } \\
\text { et al., 2009) }\end{array}$ \\
\hline
\end{tabular}

${ }^{a}$ HNC or SRFK: Cameroon National herbarium code; BUD, Herbarium of the Botany Department of the University of Dschang, Cameroon).

${ }^{b}$ Compounds characterized for the first time in Cameroonian medicinal plant are underlined.

'Screened activity: Leishmania donovani (L. donovani); Schistosoma mansoni (S. mansoni); Toxoplasma gondii (T. gondii); Trypanosoma brucei rhodesiense (T. b. rhodesiense); Trypanosoma brucei (T. brucei).

has not yet been discovered. The total number of persons affected globally is projected to rise from 246 million in 2007 to 380 million in 2025, if prevention measures will not be scaled up (Bennett, 2007). In Africa, the number of diabetic patients in 2006 was 10.4 million, and it is expected to increase to 18.7 million in 2025 .
The annual mortality linked to diabetes worldwide is estimated to be above one million. In Cameroon, the prevalence of diabetes increased from 2\% in 1998 (in a study supported by the World Diabetes Foundation, WDF) to 5\% in 2003 and 6.5\% in 2007 (in another WDF study, Walgate, 2008). Medicinal plants have been 
Table 4 | Plants used in Cameroon as anti-inflammatory and analgesic agents, with evidence of their activities.

\begin{tabular}{|c|c|c|c|c|c|}
\hline Family & Species $^{\mathrm{a}}$ & Traditional treatment & $\begin{array}{l}\text { Plant part } \\
\text { used }\end{array}$ & $\begin{array}{l}\text { Bioactive (or } \\
\text { potentially active) } \\
\text { compounds }^{\text {b }}\end{array}$ & Screened activity ${ }^{c}$ \\
\hline Caesalpiniaceae & $\begin{array}{l}\text { Erythrophleum } \\
\text { suaveolens, } \\
\text { Guillemin \& } \\
\text { Perrottet } \\
\text { (HN001AD) }\end{array}$ & $\begin{array}{l}\text { Anti-poison, dermatitis, } \\
\text { infectious disease, convulsion, } \\
\text { inflammation due to snake bite, } \\
\text { cardiac problems, headaches, } \\
\text { migraines edema, rheumatism, } \\
\text { asthma (Dalziel, 1937; } \\
\text { Bouquet, 1969; Leiderer, 1982; } \\
\text { Neuwinger, 1998) }\end{array}$ & Bark & Not identified & $\begin{array}{l}\text { Extract from the bark and } \\
\text { fractions at } 19.2 \mu \mathrm{g} / \mathrm{ml} \text { showed } \\
\text { inhibition of carrageenin-induced } \\
\text { paw edema in rats; Hexane } \\
\text { fraction inhibited the } \\
\text { 5-lipoxygenase activity (Dongmo } \\
\text { et al., 2001) }\end{array}$ \\
\hline Crassulaceae & $\begin{array}{l}\text { Kalanchoe } \\
\text { crenata Andr. } \\
\text { (50103/YA/HNC) }\end{array}$ & $\begin{array}{l}\text { Earache, smallpox, headache, } \\
\text { inflammation, pain, asthma, } \\
\text { palpitation, convulsion, general } \\
\text { debility (Dimo et al., 2006) }\end{array}$ & $\begin{array}{l}\text { Not } \\
\text { specified }\end{array}$ & Not identified & $\begin{array}{l}n \text {-Butanol fraction inhibited } \\
\text { carrageenani-, histamine-, } \\
\text { serotonin-, and formalin-induced } \\
\text { paw edema in rats (Dimo et al., } \\
\text { 2006) }\end{array}$ \\
\hline Euphorbiaceae & $\begin{array}{l}\text { Bridelia } \\
\text { scleroneura } \\
(42088 / \mathrm{HNC})\end{array}$ & $\begin{array}{l}\text { Abdominal pain, contortion, } \\
\text { arthritis, inflammation (Watt } \\
\text { and Breyer-Brandwijk, 1962; } \\
\text { Théophile et al., 2006) }\end{array}$ & $\begin{array}{l}\text { Bark, } \\
\text { roots }\end{array}$ & Not identified & $\begin{array}{l}\text { Crude bark extract showed } \\
\text { peripheral and central analgesic } \\
\text { and anti-inflammatory activity } \\
\text { against acute inflammation } \\
\text { processes in rats (Théophile et al., } \\
\text { 2006) }\end{array}$ \\
\hline Euphorbiaceae & $\begin{array}{l}\text { Uapaca } \\
\text { guineensis } \\
\text { (41501/HNC) }\end{array}$ & $\begin{array}{l}\text { Fever, inflammation, pain, skin } \\
\text { diseases, and sexual } \\
\text { dysfunction (Vivien and Faure, } \\
\text { 1996) }\end{array}$ & $\begin{array}{l}\text { Not } \\
\text { specified }\end{array}$ & Not identified & $\begin{array}{l}\text { Bark crude extract showed } \\
\text { analgesic activity, and inhibited } \\
\text { carrageenan-induced } \\
\text { inflammation in rats (Nkeh- } \\
\text { Chungag et al., 2009) }\end{array}$ \\
\hline
\end{tabular}


Table 4 | Continued

\begin{tabular}{|c|c|c|c|c|c|}
\hline Family & Species $^{\mathrm{a}}$ & Traditional treatment & $\begin{array}{l}\text { Plant part } \\
\text { used }\end{array}$ & $\begin{array}{l}\text { Bioactive (or } \\
\text { potentially active) } \\
\text { compounds }^{\text {b }}\end{array}$ & Screened activity \\
\hline Guttiferae & $\begin{array}{l}\text { Allanblackia } \\
\text { monticola } \\
\text { Staner L.C. } \\
\text { (61168/HNC) }\end{array}$ & $\begin{array}{l}\text { Amoebic dysentery, diarrhea, } \\
\text { indigestion, pulmonary } \\
\text { infections, skin diseases, } \\
\text { headache, inflammation, and } \\
\text { generalized pain (Raponda- } \\
\text { Waker and Sillans, 1961) }\end{array}$ & Bark & $\begin{array}{l}\text { Betulinic acid, lupeol, } \\
\text { and amangostin } \\
\text { (Nguemfo et al., 2009) }\end{array}$ & $\begin{array}{l}\text { Crude extract from the bark, } \\
\text { lupeol, betulinic acid, and } \\
\text { a-mangostin inhibited paw } \\
\text { carrageenan-induced edema rat } \\
\text { (Nguemfo et al., 2007, 2009) }\end{array}$ \\
\hline \multirow[t]{5}{*}{ Leguminosae } & $\begin{array}{l}\text { Erythrina } \\
\text { addisoniae } \\
\text { Hutchinson \& } \\
\text { Dalziel (41617/ } \\
\text { HNC) }\end{array}$ & $\begin{array}{l}\text { Dysentery, asthma, venereal } \\
\text { diseases, boils, and leprosy } \\
\text { (Talla et al., 2003) }\end{array}$ & Bark & $\begin{array}{l}\text { Warangalone (56) (Talla } \\
\text { et al., 2003) }\end{array}$ & $\begin{array}{l}\text { Bark extract and compound } \mathbf{5 6} \\
\text { showed an anti-inflammatory on } \\
\text { the PLA } \mathrm{A}_{2} \text {-induced paw edema and } \\
\text { 12-O-tetradecanoylphorbol } \\
\text { 13-acetate-induced ear edema in } \\
\text { mice (Talla et al., 2003) }\end{array}$ \\
\hline & $\begin{array}{l}\text { Erythrina } \\
\text { mildbraedii } \\
\text { Harms (50452/ } \\
\text { HNC) }\end{array}$ & $\begin{array}{l}\text { Dysentery, stomach pains, } \\
\text { venereal diseases, asthma, } \\
\text { female sterility, ulcers, boils } \\
\text { and various types of } \\
\text { inflammations (Oliver-Bever, } \\
\text { 1986) }\end{array}$ & $\begin{array}{l}\text { Bark, } \\
\text { roots }\end{array}$ & $\begin{array}{l}\text { Erycristagallin (57) } \\
\text { (Njamen et al., 2003) }\end{array}$ & $\begin{array}{l}\text { Root bark extract inhibited the } \\
\text { carrageenan-induced mouse paw } \\
\text { whilst compound } \mathbf{5 7} \text { inhibited the } \\
\text { PLA }{ }_{2} \text {-induced mouse paw edema } \\
\text { and mouse ear edema induced by } \\
\text { 2-O-tetradecanoylphorbol } \\
\text { 13-acetate (Njamen et al., 2003) }\end{array}$ \\
\hline & $\begin{array}{l}\text { Erythrina } \\
\text { sigmoidea Hua }\end{array}$ & $\begin{array}{l}\text { Female infertility, stomach pain, } \\
\text { and gonorrhea (Giner-Larza } \\
\text { et al., 2001) }\end{array}$ & Bark & $\begin{array}{l}\text { Sigmoidin A (51) and B } \\
\text { (52) (Njamen et al., } \\
\text { 2004) }\end{array}$ & $\begin{array}{l}\text { Compound } \mathbf{5 1} \text { inhibited } \\
\text { PLA }{ }_{2} \text {-induced paw edema in } \\
\text { mice, while both compounds } \mathbf{5 1} \\
\text { and } \mathbf{5 2} \text { were found to be effective } \\
\text { 12-O-tetradecanoylphorbol } \\
\text { 13-acetate-induced ear edema } \\
\text { (Njamen et al., 2004) }\end{array}$ \\
\hline & $\begin{array}{l}\text { Millettia } \\
\text { versicolor } \\
\text { Welw. (32315/ } \\
\text { HNC) }\end{array}$ & $\begin{array}{l}\text { Intestine parasitosis, } \\
\text { rheumatism, pain, infertility } \\
\text { (Adjanohoun et al., 1988; } \\
\text { Bouquet, 1969) }\end{array}$ & $\begin{array}{l}\text { Not } \\
\text { specified }\end{array}$ & $\begin{array}{l}\text { 2-acetyl-7- } \\
\text { methoxynaphthol[2,3-b] } \\
\text { furan-4,9-quinone (29) } \\
\text { (Fotsing et al., 2003) }\end{array}$ & $\begin{array}{l}\mathrm{CH}_{2} \mathrm{Cl}_{2} \text { fraction from methanol } \\
\text { crude bark extract inhibited } \\
\text { carrageenan-induced paw edema } \\
\text { andTPA-induced acute ear edema } \\
\text { in mouse as well as compound } \mathbf{2 9} \\
\text { (Fotsing et al., 2003) }\end{array}$ \\
\hline & $\begin{array}{l}\text { Millettia } \\
\text { griffoniana Baill. } \\
\text { (32315/SRF/ } \\
\text { HNC) }\end{array}$ & $\begin{array}{l}\text { Boils, insects bits, } \\
\text { inflammatory affections like } \\
\text { pneumonia, and asthma, } \\
\text { infertility, amenorrhea, } \\
\text { menopausal disorders } \\
\text { (Sandberg and Cronlund, 1977) }\end{array}$ & $\begin{array}{l}\text { Bark, } \\
\text { roots }\end{array}$ & $\begin{array}{l}\text { griffonianone D (55) } \\
\text { (Yankep et al., 2003) }\end{array}$ & $\begin{array}{l}\text { Extract of the root bark and } \\
\text { compound } \mathbf{5} \mathbf{5} \text { showed anti- } \\
\text { inflammatory effects via inhibition } \\
\text { of PLA_-induced mouse paw } \\
\text { edema andTPA-induced acute } \\
\text { mouse ear edema (Yankep et al., } \\
\text { 2003) }\end{array}$ \\
\hline Solanaceae & $\begin{array}{l}\text { Solanum } \\
\text { torvum Swartz. } \\
(21103 / \mathrm{HNC})\end{array}$ & $\begin{array}{l}\text { Fever, wounds, tooth decay, } \\
\text { haemostatic properties, pain, } \\
\text { anti-inflammation (Henty, 1973; } \\
\text { Ndebia et al., 2007) }\end{array}$ & Leaves & Not identified & $\begin{array}{l}\text { Crude extract from the leaves } \\
\text { inhibits both acetic acid- and } \\
\text { pressure-induced pain at } 300 \mathrm{mg} / \\
\text { kg body weight of rats, and also } \\
\text { anti-inflammatory activity on } \\
\text { carrageenan-induced paw edema } \\
\text { (Ndebia et al., } 2007\end{array}$ \\
\hline
\end{tabular}

aHN or SRFK: Cameroon National herbarium code.

${ }^{b}$ Compounds characterized for the first time in Cameroonian medicinal plant are underlined.

'Screened activity: TPA (2-O-tetradecanoylphorbol 13-acetate); PLA 2 (phospholipase $A_{2}$ ). 
reported to be useful in diabetes worldwide and have empirically been used as anti-diabetic and anti-hyperlipidemic remedies. Antihyperglycemic effects of these plants were attributed to their ability to restore the function of pancreatic tissues by increasing insulin output, inhibiting the intestinal absorption of glucose, or enhancing metabolism of insulin-dependent processes. Several plant preparations were traditionally used in Cameroon to treat diabetes. Some of them were screened for their bioactivity, but most of the studies were not pursued until the isolation of active principles. Plants with hypoglycaemic activities include Anacardium occidentale, Sclerocarya birrea, Ageratum conyzoides, Ceiba pentandra, Kalanchoe crenata, Bridelia ndellensis, Irvingia gabonensis, Bersama engleriana and Morinda lucida (Table 5).

\section{ANTIOXIDANT ACTIVITIES}

The common link between oxidants and inflammatory reactions, infections, cancer, and other disorders has been well established (Mongelli et al., 1997; Wang et al., 1999). However, this may not really be of therapeutic relevance, but more of a preventive medicine. In chronic infections and inflammation as well as in other disorders, release of leukocytes and other phagocytic cells readily defends the organism from further injury. The cells do this by releasing free oxidant radicals, and these by-products are generally reactive oxygen species (ROS) such as super oxide anion, hydroxyl radical, nitric oxide, and hydrogen peroxide that result from cellular redox processes (Ames et al., 1993; Mongelli et al., 1997). At low or moderate concentrations, ROS exert beneficial effects on cellular responses and immune function. At high levels, however, free radicals and oxidants generate oxidative stress, a deleterious process that can damage cell structures, including lipids, proteins, and DNA (Pham-Huy et al., 2008). Oxidative stress plays a major role in the development of chronic and degenerative ailments such as cancer, autoimmune disorders, rheumatoid arthritis, cataract, aging, cardiovascular, and neurodegenerative diseases (Willcox et al., 2004b; Pham-Huy et al., 2008). Antioxidants act as free radical scavengers by preventing and repairing damages caused by ROS and, therefore, can enhance the immune defense and lower the risk of cancer and degenerative diseases (Ames et al., 1993; Pham-Huy et al., 2008). In recent years, there is an increasing interest in finding antioxidant phytochemicals, because they can inhibit the propagation of free radical reactions, and thereby protect the human body from diseases (Terao and Piskula, 1997). Several medicinal plants of Cameroon were screened for their antioxidant properties and a number of bioactive compounds was isolated (Table 6). Omisore et al. (2005) considered the cut-off point for antioxidant activity as $50 \mu \mathrm{g} / \mathrm{ml}$. Samples with $\mathrm{IC}_{50}>50 \mu \mathrm{g} / \mathrm{ml}$ were classified as being moderately active, while samples with $\mathrm{IC}_{50}<50 \mu \mathrm{g} / \mathrm{ml}$ were judged as having high antioxidant capacity. In the present paper, samples will be considered to have high or significant antioxidant capacity with $\mathrm{IC}_{50}<50 \mu \mathrm{g} / \mathrm{ml}$ (extract) or $\mathrm{IC}_{50}<10 \mu \mathrm{g} / \mathrm{ml}$ (compounds), moderate antioxidant capacity with $50<\mathrm{IC}_{50}<100 \mu \mathrm{g} /$ $\mathrm{ml}$ (extract) or $10<\mathrm{IC}_{50}<20 \mu \mathrm{g} / \mathrm{ml}$ (compounds) and low antioxidant capacity with $\mathrm{IC}_{50}>100 \mu \mathrm{g} / \mathrm{ml}$ (extract) or $\mathrm{IC}_{50}>20 \mu \mathrm{g} /$ $\mathrm{ml}$ (compounds). Extracts from 42 medicinal plants of Cameroon used for the treatment of anemia, diabetes, AIDS, malaria, and obesity were recently screened for antioxidant properties, with a considerable number showing good activities (Agbor et al., 2007). Many of them exhibited high inhibition percentages on the basis of Folin, Ferric reducing antioxidant power (FRAP), and DPPH (1,1-diphenyl-2-picrylhydrazyl) assays. Plants with good activities included Alchornea cordifolia (Euphorbiaceae), Dacryodes edulis (Burseraceae), Ocimum basilicum (Lamiaceae), Harungana madagascariensis (Hypericaceae), Cylicodiscus gabunensis (Mimosaceae), Coleus coprosifolius (Lamiaceae) (Agbor et al., 2007). Arylbenzofurans isolated from the bark of Morus mesozygia (Moraceae), moracin T (43), moracin U (44), moracin S (45); moracin $\mathrm{R}$ (46) also showed strong DPPH scavenging capability with $\mathrm{IC}_{50}$ values of $4.12,5.06,6.08$, and $7.17 \mu \mathrm{g} / \mathrm{ml}$, respectively (Kapche et al., 2009). The activity of the crude extract of this plant was also reported as significant $\left(\mathrm{IC}_{50}: 5.92 \mu \mathrm{g} / \mathrm{ml}\right)$, by means of the DPPH scavenging assay (Kapche et al., 2009).

\section{OTHER ACTIVITIES}

Other studies involving Cameroon medicinal plants include their action on human fertility and enzymatic activities. However, few studies have focused on these activities, explaining the scarcity of published data.

Some plants with positive effects on the reproductive system based on studies using experimental rats have been reported. They include Aloe buettneri (Liliaceae), Justicia insularis and Dicliptera verticillata (Acanthaceae) and Hibiscus macranthus (Malvaceae), locally used to regulate the menstrual cycle and to treat dysmenorrhea or infertility in women (Telefo et al., 1998); Basella alba (Basellaceae) (Moundipa et al., 2005), and Mondia whitei (Periplocaceae) traditionally claimed to increase libido (Watcho et al., 2001).

Some compounds from Cameroonian plants were investigated for the ability to interfere with the activity of some enzymes such as xanthine oxidase, phosphodiesterase I, or prolyl endopeptidase. Xanthine oxidase catalyzes the oxidative hydroxylation of hypoxanthine or xanthine using oxygen as a cofactor, and the resulting end products are superoxide anion $\left(\mathrm{O}_{2}{ }^{-}\right)$and uric acid. The inhibitors of xanthine oxidase enzyme can prevent the generation of excess superoxide anions (Chung et al., 1997). Phosphodiesterase I successively hydrolyzes 5 -mononucleotides from 3'-hydroxylterminated ribo- and deoxyribo-oligonucleotides. The enzyme has been widely utilized as a tool for structural and sequential studies of nucleic acids. The $5^{\prime}$-nucleotide phosphodiesterase isozyme-V test is useful in detecting liver metastatis in breast, gastrointestinal, lung, and various other forms of cancers (Lei-Injo et al., 1980). Prolyl endopeptidase catalyzes the hydrolysis of peptide bonds at the L-proline carboxy terminal and, thus, plays an important role in the biological regulation of proline-containing neuropeptides and peptide hormones, which are recognized to be involved in learning and memory (Szeltner et al., 2000). The stilbene glycosides isolated from Boswellia papyrifera (Del.) Hochst (Burseraceae), trans-4',5dihydroxy-3-methoxystilbene-5- $O-\{\alpha$-L-rhamnopyranosyl-(1-2)[ $\alpha$-L-rhamnopyranosyl-(1-6)]- $\beta$-D-glucopyranoside and trans- $4^{\prime}$, 5-dihydroxy-3-methoxystilbene-5- $O$-[ $\alpha$-L-rhamnopyranosyl(1-6)]- $\beta$-D-glucopyranoside exhibited significant inhibition of phosphodiesterase I and xanthine oxidase (Atta-ur-Rahman et al., 2005). Triterpenes such as 3 - $\alpha$-acetoxy-27-hydroxylup20(29)-en-24-oic acid, 11-keto- $\beta$-boswellic acid, $\beta$-elemonic 


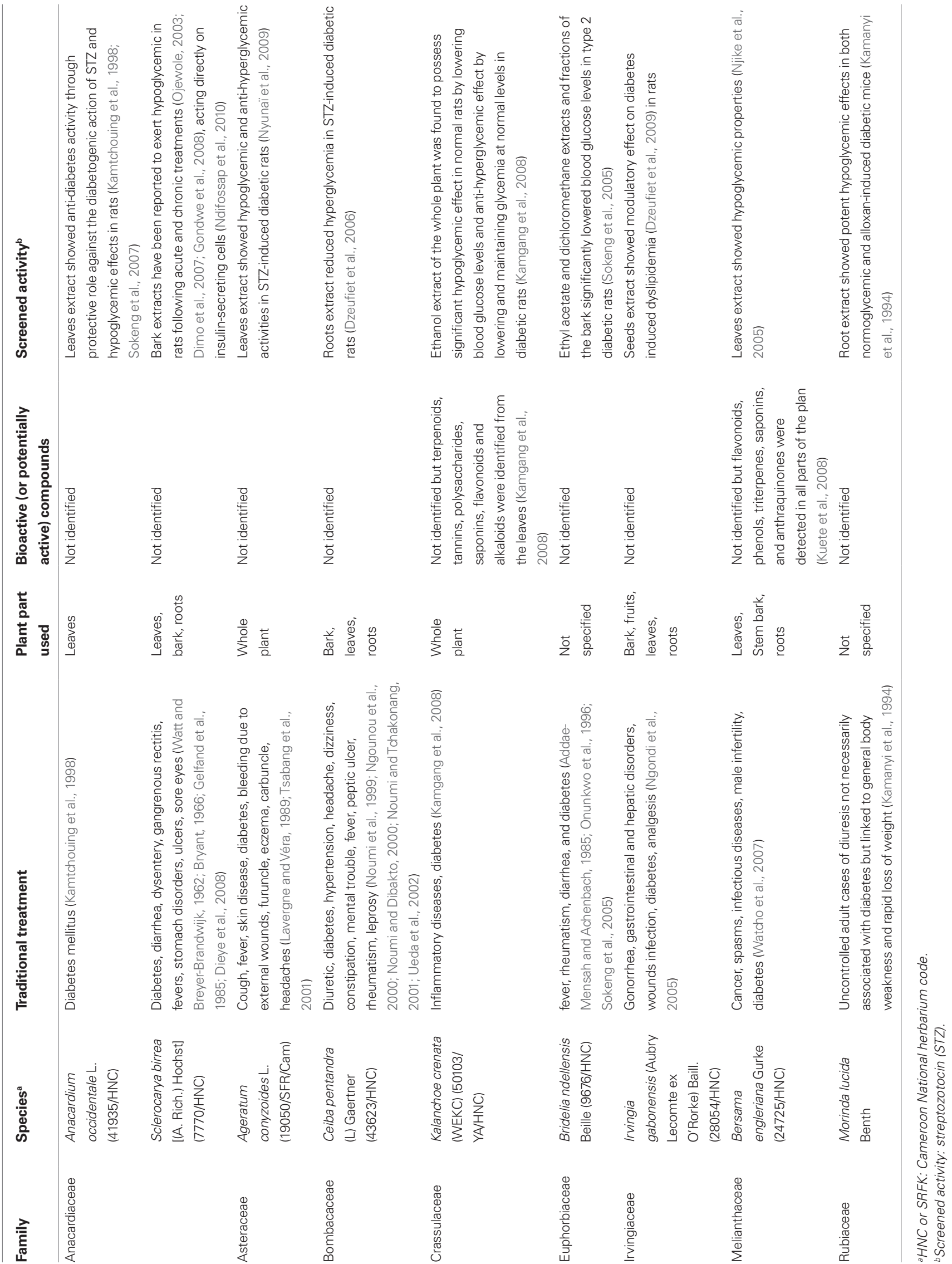


Table 6 | Plants used in Cameroon with evidence of their as antioxidant activities.

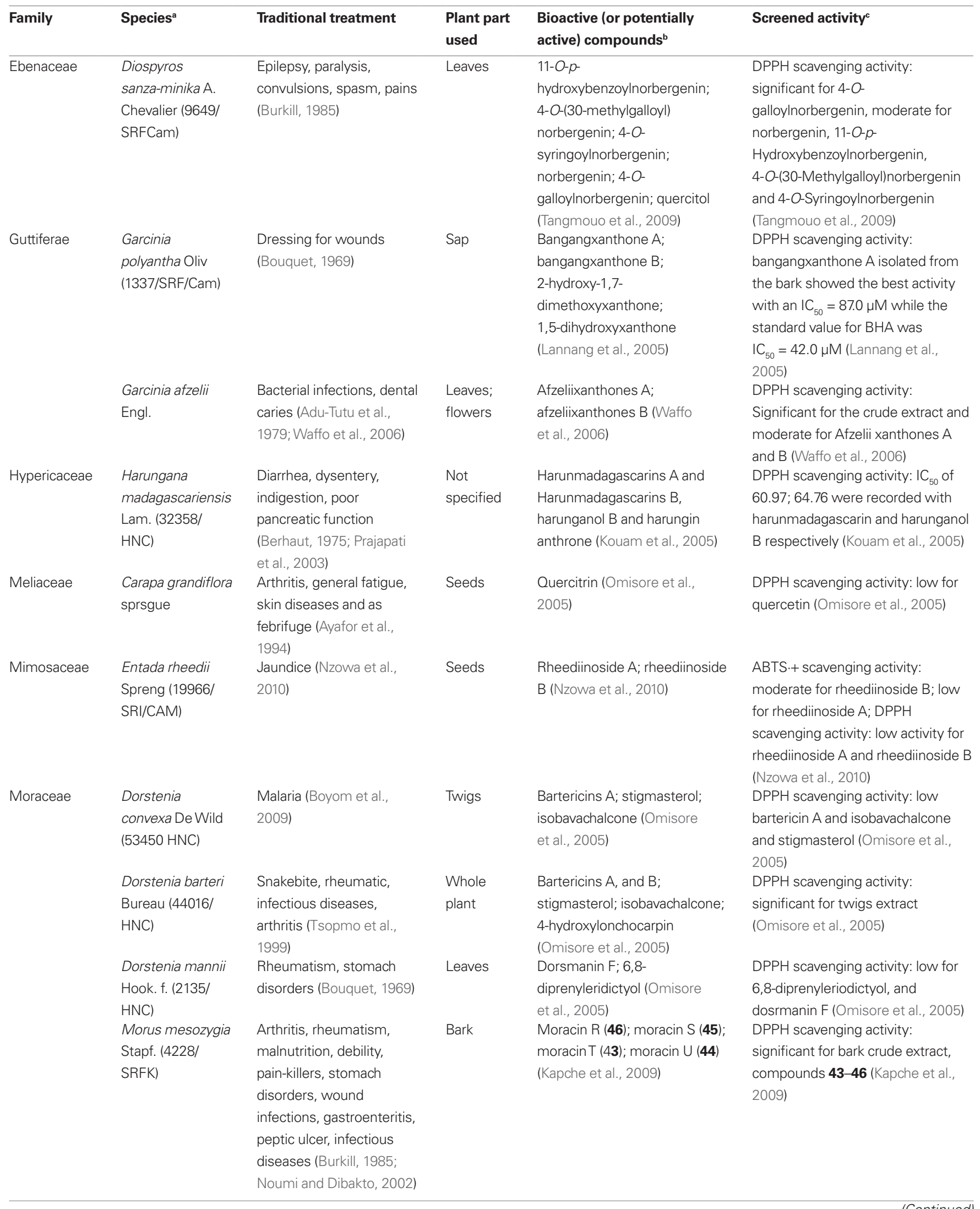


Table 6 | Continued

\begin{tabular}{|c|c|c|c|c|c|}
\hline Family & Species $^{a}$ & Traditional treatment & $\begin{array}{l}\text { Plant part } \\
\text { used }\end{array}$ & $\begin{array}{l}\text { Bioactive (or potentially } \\
\text { active) compounds }{ }^{b}\end{array}$ & Screened activity ${ }^{c}$ \\
\hline Piperaceae & $\begin{array}{l}\text { Piper umbellatum } \\
\text { Linn (6516/SRF/ } \\
\text { CAM) }\end{array}$ & $\begin{array}{l}\text { Poisoning, pitting edema, } \\
\text { fetal malpresentation, } \\
\text { filariasis, rheumatism, } \\
\text { hemorrhoids, } \\
\text { dysmenorrheal, general } \\
\text { pains (Tabopda et al., } \\
\text { 2008) }\end{array}$ & $\begin{array}{l}\text { Whole } \\
\text { plant }\end{array}$ & $\begin{array}{l}\text { Piperumbellactams A; } \\
\text { piperumbellactams B; } \\
\text { piperumbellactams C; } \\
\text { N-p-coumaroyl tyramine } \\
\text { (Tabopda et al., 2008) }\end{array}$ & $\begin{array}{l}\text { DPPH scavenging activity: } \\
\text { Moderate activity reported for } \\
\text { piperumbellactams } A \text { and low } \\
\text { activities for piperumbellactams B; } \\
\text { C; } N \text {-p-coumaroyl tyramine } \\
\text { (Tabopda et al., 2008) }\end{array}$ \\
\hline
\end{tabular}

aHC or SRFK: Cameroon National herbarium code.

${ }^{b}$ Compounds characterized for the first time in Cameroonian medicinal plant are underlined.

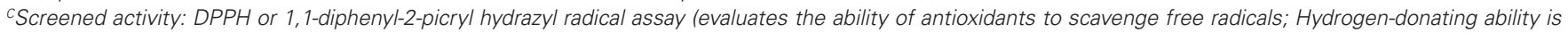

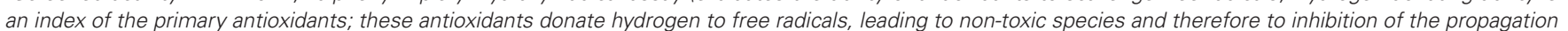

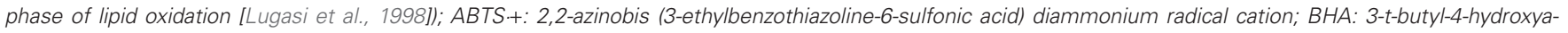
nisole; Significant activity $\left(I C_{50}<50 \mu \mathrm{g} / \mathrm{ml}\right)$, moderate activity $\left(50<1 C_{50}<100 \mu \mathrm{g} / \mathrm{m} /\right)$, low activity $\left(I C_{50}>100 \mu \mathrm{g} / \mathrm{m} /\right)$.

acid, $3 \alpha$-acetoxy-11-keto- $\beta$-boswellic acid, and $\beta$-boswellic acid also exhibited prolyl endopeptidase inhibitory activities (Atta-urRahman et al., 2005).

\section{CONCLUSION}

The present review presents an overview of medicinal plants research in Cameroon and is intended to serve as scientific baseline information for the documented plants as well as a starting point for future studies. The paper draws attention on some active metabolites and plant extracts, with the potential for new drugs or improved plant medicines. The review inevitably shows the richness of the Cameroon flora as medicinal resource and demonstrates the effectiveness of numerous traditionally used plants. Presently, there is an urgent necessity for standardization of plant-derived drugs, as their use is still empirical. There is also an urgent requirement

\section{REFERENCES}

Addae-Mensah, I., and Achenbach, H. (1985). Terpenoids and flavonoids of Bridelia ferruginea. Phytochemistry 24 , 1817-1819.

Adjanohoun, E. J., Ahyi, A. M. R., Ake Assi, L., Moutsambote, J. M., Mpati, J., Doulou, V., and Baniakina, J. (1988). Médecine Traditionnelleet Pharmacopée: ContributionauxÉtudesEthnobotaniques et Floristiquesen République Populaire du Congo. Paris: Rapport ACCT.

Adjanohoun, J.E., Aboubakar, N., Dramane, K., Ebot, M. E., Ekpere, J. A., EnowOrock, E. G., Focho, D., Gbile, Z. E., Kamanyi, A., Kamsu Kom, J., Keita, A., Mbenkum, T., Mbi, C. N., Mbiele, A. L., Mbome, I. L., Miburu, N. K., Nancy, W. L.,Nkongmeneck,B.,Satabie,B.Sofowora, A., Tamze, V., and Wirmum, C.K. (1996). Traditional MedicineandPharmacopoeia: Contribution toEthnopharmacologicaland Floristic Studies in Cameroon. LagosNigeria: OAU/STRC.

Adu-Tutu, M., Afful, Y., Asante-Appiah, K., Lieberman, D., Hall, J. B., and
Elvin-Lewis, M. (1979). Chewing stick usage in southern Ghana. Econ. Bot. $33,320-328$.

Agbor, G. A., Kuate, A., and Oben, J. E. (2007). Medicinal plants can be good source of antioxidant: Case study in Cameroon. Pak. J. Biol. Sci. 10, 537-544.

Ames, B. N., Shigenaga, M. K., and Hagen, T. M. (1993). Oxidants, antioxidants and the degenerative diseases of aging. Proc. Natl. Acad. Sci. U.S.A. 90, 7915-7922.

Ammah, A., Nkuo-Akenji, T., Ndip, R., and Deas, J.E. (1999). An update on concurrent malaria and typhoid fever in Cameroon. Trans. R. Soc. Trop. Med. Hyg. 93, 127-129.

Anonymous. (2006). Plan stratégique national de développement et d'intégration de la médicine traditionnelle au Cameroun 2006-2010. http://www.irad-cameroon.org/Docs/ Documents/1138721168 new_year_ speach_SG_d\%C3\%A9finitif.doc. (Accessed on May 04, 2010).

to standardize methods and cut-off points for describing their bioactivities. Other recommendations include parallel screenings by using cytotoxicity tests to preclude non-specific cytotoxicity from being interpreted as efficient following in vitro screening. The elucidation of the mechanisms of action of biologically active extracts and compounds should be strengthened and given priority in future investigations as already shown for natural products from other parts of the world (Kong et al., 2009; Youns et al., 2010; Konkimalla and Efferth, 2010).

\section{ACKNOWLEDGMENTS}

Authors are grateful to Dr. H.M. Poumale (Faculty of Science, University of Yaoundé I) for his support. Victor Kuete is also thankful to the Deutscher Akademische Austausch Dienst (DAAD) for the postdoctoral fellowship at the University of Mainz, Germany.

Asongalem, E. A., Foyet, H. S., Ekobo, S. Dimo, T., and Kamtchouing, P. (2004). Antiinflammatory, lack of central analgesia and antipyretic properties of Acanthusmontanus(Ness) T.Anderson. J. Ethnopharmacol. 95, 63-68.

Atta-ur-Rahman, Naz, H., Fadimatou, Makhmoor, T., Yasin, A., Fatima, N., Ngounou, F. N., Kimbu, S. F., Sondengam, B. L., and Iqbal Choudhary, M. I. (2005). Bioactive constituents from Boswellia papyrifera. J. Nat. Prod. 68, 189-193.

Aubreville, A. (1950). Flore Forestière Soudano-Guinéene A.O.F. Cameroun Paris: A.E.F, Société d'Edition Géographique Maritime et Coloniale.

Ayafor, J. F., Kimbu, S. F., and Ngadjui, B. T. (1994). Limonoids from Curupa Carapa grandifolia (Meliaceae). Tetrahedron 50, 9343-9354.

Babu, B. H., Shulesh, B. S., and Padikkala, J. (2001). Antioxidant and hepatoprotective effect of Acanthus ilicifolius (Acanthaceae). Fitoterapia 72, 272-277.
Bennett, P. (2007). New data, fresh perspectives: diabetes atlas, third edition. Diabetes Voice 52, 46-48.

Berhaut, J. (1975). Flore Illustrée du Sénégal, Tome IV Dakar: Préface de M. Leopold Sendar Senghor.

Bessong, P. O., Obi, C. L., Igumbor, E., Andreola, M.-L., and Litvak, S. (2004). In vitro activity of three selected South African medicinal plants against human immunodeficiency virus type 1 reverse transcriptase. Afr. J. Biotechnol. 3, 555-559.

Bickii, J., Feuya Tchouya, G. R., Tchouankeu, J. C., and Tsamo, E. (2007a). The antiplasmodial agents of the stem bark of Entandrophragma angolense (Meliaceae). Afr. J. Trad. CAM 4, 135-139.

Bickii,J., Feuya Tchouya, G.R., Tchouankeu, J.C., and Tsamo,E.(2007b).Antimalarial activity in crude extracts of some Cameroonian medicinal plants. Afr. J. Trad. CAM 4, 107-111.

Bickii, J., Njifutie, N., Foyere, J. A., Basco, L. K., and Ringwald, P. (2000). In vitro 
antimalarial activity of limonoids from Khaya grandifoliola C.D.C. (Meliaceae). J. Ethnopharmacol. 69, 27-33.

Boik, J. (2001). Natural Compounds in Cancer Therapy. Minnesota, USA: Oregon Medical Press.

Boyom, F. F., Kemgne, E. M., Tepongning, R., Ngouana, V., Mbacham, W. F., Tsamo, E., Amvam Zollo, P. H., Gut, J., and Rosenthal, P. J. (2009). Antiplasmodial activity of extracts from seven medicinal plants used in malaria treatment in Cameroon. J. Ethnopharmacol. 123, 483-488.

Bouquet,A.(1969). Féticheurs et médécines traditionnelles du Congo (Brazzaville). Paris: ORSTOM.

Brahemi, G., Kona, F. R., Fiasella, A., Buac, D., Soukupov, J., Brancale, A., Burger, A. M., and Westwell, A. D. (2010). Exploring the structural requirements for inhibition of the ubiquitin E3 ligase breast cancer associated protein 2 (BCA2) as a treatment for breast cancer. J. Med. Chem. 53, 2757-2765.

Bray, D. H., Warhurst, D. C, Connolly, J. D., O'Neill, M. J., and Phillipson, J. D. (1990). Plants as sources of antimalarial drugs. Part 7. Activity of some species of Meliaceae and their constituent limonoids. Phytother. Res. 4, 29-35.

Bryant, A. T. (1966). Zulu Medicine and Medicine Men. Cape Town: Struik C.

Burkill, H. M. (1985). Useful Plants of West Tropical Africa. Edinburgh: Royal Botanic Garden.

Calas, M., Cordina, G., Bompart, J., Bari, M. B., Jei, T., Ancelin, M. L., and Vial, H. (1997). Antimalarial activity of molecules interfering with plasmodium falciparum phospholipid metabolism. Structure-activity relationship analysis. J. Med. Chem. 40, 3557-3566.

Castro-Leal, J., Dayton, L., and Mehra, K. (2000). Public spending on health care in Africa: do the poor benefit? Bull. World Health Organ. 78, 66-74.

Cheek, M. (2004). Thecacoris annobonae. IUCN 2009. IUCN Red List of Threatened Species. http:// www.iucnredlist.org/apps/redlist/ details/45457/0. (Accessed on April 13, 2008).

Chung, H. Y., Baek, B. S., Song, S. H., Kim, M. S., Huh, J. I., Shim, K. H., Kim, K. W., and Lee, K. H. (1997). Xanthine dehydrogenase/xanthine oxidase and oxidative stress. Age (Omaha) 20, 127-140.

Cos, P., Vlietinck, A. J., Vanden Berghe, D., and Maes, L. (2006). Antiinfective potential of natural products: How to develop a stronger in vitro 'proof-of-concept'.J. Ethnopharmacol. 106, 290-302.

Croft, S. L., Barrett, M. P., and Urbina, J. A. (2005). Chemotherapy of trypano- somiases and leishmaniasis. Trends Parasitol. 21, 508-512.

Dalziel, J. M. (1937). The Useful Plants of West Tropical Africa. London: The Crown Agents for the Colonies.

Dieye, A. M., Sarr, A., Diop, S. N., Ndiaye, M., Sy, G. Y., Diarra, M., Rajraji Gaffary, I., Ndiaye Sy, A., and Faye, B. (2008). Medicinal plants and the treatment of diabetes in Senegal: survey with patients. Fundam. Clin. Pharmacol. 22, 211-216.

Dimo, T., Fotio, A. L., Nguelefack, T. B., Asongalem, E. A., and Kamtchouing, P. (2006). Antiinflammatory activity of leaf extract of Kalanchoe crenata Andr. Indian J. Phamacol. 38, 115-119.

Dimo, T., Rakotonirina, S. V., Tan, P. V., Azay, J., Dongo, E., Kamtchouing, P., and Cros, G. (2007). Effect of Sclerocarya birrea (Anacardiaceae) stem bark methylene chloride/ methanol extract on streptozotocindiabetic rats. J. Ethnopharmacol. 110, 434-438.

Dongmo, A. B., Kamanyi, A., Anchang, M. S., Chungag-Anye Nkeh, B., Njamen, D., Nguelefack, T. B., Nole, T., and Wagner,H. (2001).Anti-inflammatory and analgesic properties of the stem bark extracts of Erythrophleum suaveolens (Caesalpiniaceae), Guillemin \& Perrottet. J. Ethnopharmacol. 77 , 137-141.

Dzeufiet, P. D. D., Ngeutse, D. F., Dimo, T., Tédong, L., Ngueguim, T. F., Tchamadeu, M. C, Nkouambou, N. C., Sokeng, S. D., and Kamtchouing, P. (2009). Hypoglycemic and hypolipidemic effects of Irvingia gabonensis (Irvingiaceae) in diabetic rats. Pharmacologyonline 2, 957-962.

Dzeufiet, P. D. D., Tédong, L., Asongalem, E. A., Dimo, T., Sokeng, S. D., and Kamtchouing, P. (2006). Hypoglucaemic effect of methylène chloride/methanol root extract of Ceiba pentandra in normal and diabetic rats. Indian J. Pharmacol. 38, 194-197.

EarthTrends. (2003). Biodiversity and Protected Areas-Cameroon. http:// earthtrends.wri.org/pdf_library/ country_profiles/bio_cou_120.pdf. (Accessed on May 04, 2010).

Edmondson, J. (2001). Malaria and Poverty: Opportunities to Address Malaria through Debt Relief and Poverty Reduction Strategies. www. lshtm.ac.uk/itd/dcvbu/malcon. (Accessed on November 08, 2009).

Ekwalla, N., and Tongo, E. (2003). Nos plantes qui soignent. Doula, Cameroon: Ed I.C.

Eyong, K. O., Kumar, P. S., Kuete, V., Folefoc, G. N., Nkengfack, A. E., and Baskaran, S. (2008). Semisynthesis and antitumoral activity of 2-acetyl- furanonaphthoquinone and other naphthoquinone derivatives from lapachol. Bioorg. Med. Chem. Lett. 18, 5387-5390.

Ezeamuzie, I. C., Ojinnake, M. C., Uzygna, E. O., and Oji, S. E. (1994). Antiinflammatory, antipyretic and antimalarial activity of a West African medicinal plant-Picralima nitida. Afr. J. Med. Sci. 23, 85-90.

Fairlamb, A. (2003). Chemotherapy of human African trypanosomiasis: current and future prospects. Trends Parasitol. 19, 488-494.

Fakeye, T. O., Itiola, O. A., and Odelila, H. A. (2000). Evaluation of the antimicrobial property of the stem bark of Picralima nitida (Apocynaceae). Phythother. Res. 14, 368-370.

Focho, D. A., Newu, M. C., Anjah, M. G., Nwana, F. A., and Ambo, F. B. (2009). Ethnobotanical survey of trees in Fundong, Northwest Region, Cameroon. J. Ethnobiol. Ethnomed. $5,17$.

Fotie, J., Bohle, D. S., Olivier, M., Gomez, M. A., and Nzimiro, S. (2007). Trypanocidal and antileishmanial dihydrochelerythrine derivatives from garcinia lucida. J. Nat. Prod. 70, 1650-1653.

Fotio, A. L., Dimo, T., Ngo Lemba, E., Temdie, R. J., Ngueguim, F., and Kamtchouing, P. (2009). Acute and chronic anti-inflammatory properties of the stem bark aqueous and methanol extracts of Sclerocarya birrea (Anacardiaceae). InflammoPharmacology 17 , 229-237.

Fotsing, M. T., Yankep, E., Njamen, D., Fomum, Z. T., Nyasse, B., Bodo, B., Recio, M. C., Giner, R. M., and Rios, J. L. (2003). Identification of an AntiInflammatory principle from the stem bark of Millettia versicolor. Planta Med. 69, 767-770.

Gelfand, M., Mavi, S., Drummond, R. B., and Ndemera, B. (1985). The Traditional Medical Practitioner in Zimbabwe. Gweru, Zimbabwe: Mambo Press.

Giner-Larza, E. M., Manez, S., Recio, M. C., Giner, R. M., Prieto, J. M., CerdaNicolas, M., and Rios, J. L. (2001). Oleanonic acid, a 3-oxotriterpene from Pistacia, inhibits leukotriene synthesis and has anti-inflammatory activity. Eur. J. Pharmacol. 428 137-143.

Gondwe, M., Kamadyaapa, D. R., Tufts, M., Chuturgoon, A. A., and Musabayane, C. T. (2008). Sclerocarya birrea [(A. Rich.) Hochst.] [Anacardiaceae] stem-bark ethanolic extract (SBE) modulates blood glucose, glomerular filtration rate (GFR) and mean arterial blood pressure (MAP) of STZ- induced diabetic rats. Phytomedicine 15, 699-709.

Henty, E. E. (1973). Weeds of New Guinea and their Control. Department of Forests, Division of Botany. Botany Bulletin. No. 7. Lae, Papua New Guinea, pp. 149-151.

Hostettmann, K., Marston, A., Ndjoko, K., and Wolfender, J. L. (2000). The potential of African plants as source of drugs. Curr. Org. Chem. 4, 973-1010.

Igoli, J. O., Igoji, O. G., Tor-Anylin, T. O., and Ogali, N. O. (2005). Traditional medicinal practice amongst the Igede people of Nigeria, part II. Afr. J. Trad. CAM 2, 134-152.

Index mundi. (2008). Cameroon Major Infectious Diseases. http://www.indexmundi.com/cameroon/major_infectious_diseases.html. (Accessed on August 02, 2009).

Irvine, F. R. (1961). Woody Plants of Ghana. London: Oxford University Press.

Iwu, M. M. (1993). Handbook of African Medicinal Plants. London: CRC Press.

Jain, K. N., Kulkarni, K. S., and Singh, A. (2002). Modulation of NSAIDinduced antinociceptive and anti-inflammatory effects by (2-adrenoceptor agonists with gastroprotective effects. Life Sci. 70, 2857-2869.

Jatsa, H. B., Ngo Sock, E. T., Tchuem Tchuente, L. A., and Kamtchouing, P. (2009). Evaluation of the in vivo activity of different concentrations of Clerodendrum umbellatum poir against Schistosoma mansoni infection in mice. Afr. J. Trad. CAM 6 , 216-221.

Jing, H., Zhou, X., Dong, X., Cao, J., Zhu, H., Lou, J., Hu, Y., He, Q., and Yang, B. (2010). Abrogation of Akt signaling by Isobavachalcone contributes to its anti-proliferative effects towards human cancer cells. Cancer Lett. 294, 167-177.

Jiofack, T., Fokunang, C., Guedje, N., Kemeuze, V., Fongnzossie, E. Nkongmeneck, B.A., Mapongmetsem, P. M., and Tsabang, N. (2010). Ethnobotanical uses of medicinal plants of two ethnoecological regions of Cameroon. Int. J. Med. Sci. 2, 60-79.

Jones, K. D. J., Hesketh, T., and Yudkin, J. (2008). Extensively drug-resistant tuberculosis in sub-Saharan Africa: an emerging public-health concern. Trans. R. Soc. Trop. Med. Hyg. 102, 219-214.

Kamanyi, A., Njamen, D., and Nkeh, B. (1994). Hypoglycaemic properties of the aqueous root extract of Morinda lucida (Benth) (Rubiaceae). Studies in the Mouse. Phytother. Res 8, 369-371. 
Kamgang, R., Mboumi, R. Y., Fondjo, A. F., Tagne, M. A. F., N'dille, G. P. R. M., and Yonkeu, J. N. (2008). Antihyperglycaemic potential of the water-ethanol extract of Kalanchoe crenata (Crassulaceae). J. Nat. Med. 62, 34-40.

Kamtchouing,P., Sokeng, S.D., Moundipa, P. F., Watcho, P., Jatsa, H. B., and Lontsi, D. (1998). Protective role of Anacardium occidentale extract against streptozotocin-induced diabetes in rats. J. Ethnopharmacol. 62, 95-99.

Kapche, G. D. W. F., Fozing, C. D., Donfack, J. H., Fotso, G. W., Amadou, D., Tchana, A. N., Bezabih, M., Moundipa, P. F., Ngadjui, B. T., and Abegaz, B. M. (2009). Prenylated arylbenzofuran derivatives from Morus mesozygia with antioxidant activity. Phytochemistry 70, 216-221.

Kenmogne, M., Prost, E., Harakat, D., Jacquier, M. J., Frédérich, M., Sondengam, L. B., Zèches, M., and Waffo-Téguo, P. (2006). Five labdane diterpenoids from the seeds of Aframomum zambesiacum. Phytochemistry 67, 433-438.

Koné, P.D. (1997). Natureet Faune, Vol. 13 Acrra, Ghana: F.A.O. Regional Office for Africa.

Kong, Y., Ma, W., Liu, X., Zu, Y., Fu, Y., Wu, N., Liang, L., Yao, L., and Efferth, T. (2009). Cytotoxic activity of cucurmin towards CCRF-CEM leukemia cells and its effect on DNA damage. Molecules 14, 5328-5338.

Konkimalla, V. B., and Efferth, T. (2010). Inhibition of epidermal growth factor receptor-overexpressing cancer cells by camptothecin, 20-(N,N-diethyl) glycinate. Biochem. Pharmacol. 80, 39-49.

Kouam, S. F., Ngadjui, B. T., Krohn, K., Wafo, P., Ajaz, A., and Choudhary, M. I. (2005). Prenylated anthronoid antioxidants from the stem bark of Harungana madagascariensis. Phytochemistry 66, 1174-1179.

Kuete, V. (2010a). Potential of Cameroonian plants and derivedproducts against microbial infections: a review. Planta Med. 76, 1-13.

Kuete, V., Poumale Poumale, H. M., Guedem, A. N., Shino, Y., Randrianasolo, R., and Ngadjui, B. T. (2010b). Antimycobacterial, antibacterial and antifungal activities of the methanol extract and compounds from Thecacoris annobonae (Euphorbiaceae), S. Afr. J. Bot. 76, 536-542.

Kuete, V., Ngameni, B., Tangmouo, J. G., Bolla, J. M., Alibert-Franco, S., Ngadjui, B. T., and Pagès, J. M. (2010c). Efflux pumps are involved in the defense of Gram-negative bacteria against the natural products isobavachalcone and diospyrone. Antimicrob. Agents Chemother. 54, 1749-1752.

Kuete, V., Mbaveng, A. T., Tsaffack, M., Beng, V. P., Etoa, F. X., Nkengfack, A. E., Marion Meyer, J. J., and Lall, N. (2008). Antitumor, antioxidant and antimicrobial activities of Bersama engleriana (Melianthaceae). J. Ethnopharmacol. 115, 494-501.

Kuete, V., Vouffo, B., Mbaveng, A. T., Vouffo, E. Y., Siagat, R. M., and Dongo, E. (2009). Evaluation of Antiaris africana methanol extract and compounds for antioxidant and antitumor activities. Pharm. Biol. 47, 1042-1049.

Lannang, A. M., Komguem, J., Ngninzeko, F. N., Tangmouo, J. G., Lontsi, D., Ajaz, A., Choudhary, M. I., Ranjit, R., Devkota, K. P., and Sondengam, B. L. (2005). Bangangxanthone A and $\mathrm{B}$, two xanthones from the stem bark of Garcinia polyantha Oliv. Phytochemistry 66, 2351-2355.

Lavergne, R., and Véra, R. (1989). Etude Ethnobotanique des Plantes Utilisées Dans la Pharmacopée Traditionnelle à la Réunion. Médecine Traditionnelle et Pharmacopée. Paris: Agence de Coopération Culturelle et Technique.

Leiderer. (1982). La médécine traditionnelle chez les Bekpak (Bafia) du Cameroun. St. Augustin, Deutschland: Haus Volker und kulturen.

Lei-Injo, L. E., Tsou, K. C., Lo, K. W., Lopez, C. G., Balasegaram, M., and Ganesan, S. (1980). 5'-Nucleotide phosphodiesterase isozyme- $\mathrm{V}$ in health, in cancer, and in viral hepatitis. Cancer 45, 795-798.

Lenta, B. N., Tantangmo, F., Devkota, K. P., Wansi, J. D., Chouna, J. R., Fongang Soh, R. C., Neumann, B., Stammler, H. G., Tsamo, E., and Sewald, N. (2009). Bioactive constituents of the stem bark of Beilschmiedia zenkeri. J. Nat. Prod. 72, 2130-2134.

Letouzey, R. (1985). Carte phytogéographique du Cameroun au 1/500000e. Toulouse: Institut de la Carte Internationale de la Végétation.

Lewis, M. A., Arnason, J. T., Philogene, B. J.R., Rupprecht, J.K., and McLaughlin, J. L. (1993). Inhibition of respiration at site I by asimicin, an insecticidal acetogenin of the Pawpaw Asimina triloba (Annonaceae). Pestic. Biochem. Physiol. 45, 15-23.

Lima, N. M. F., Correia, C. S., Leon, L. L., Machado, G. M. C., Madeira, M. D. F., Santana, A. E. G., and Goulart, M. O. F. (2004). Antileishmanial activity of lapachol analogues.Mem. Inst. Oswaldo Cruz Rio de Janeiro 99, 757-761.

Luft, B. J., and Remington, J. S. (1992). Toxoplasmic encephalitis in AIDS. Clin. Infect. Dis. 15, 211-222.
Lugasi, A., Dworschak, E., Blazovics, A. and Kery, A. (1998). Antioxidant and free radical scavenging properties of squeezed juice from black radish (Raphanus sativus L., var. niger) root. Phytother. Res. 12, 502-506.

Mahmoudi, N., De Julian-Ortiz, J. V., Ciceron, L., Galvez, J., Mazier, D., Danis, M., Derouin, F., and GarciaDomenech, R. (2006). Identification of new antimalarial drugs by linear discriminant analysis and topological virtual screening. J. Antimicrob. Chemother. 57, 489-497.

Malviya, N., Jain, S., and Malviya, S. (2010). Antidiabetic potential of medicinal plants. Acta Pol. Pharm. Drug Res. 67, 113-118.

Mayfield, J. (1998). New classification and diagnostic criteria for diabetes mellitus. Am. Fam. Physician 58, 1355-1370.

McGaw, L. J., Lall, N., Meyer, J. J. M., and Eloff, J. N. (2008). The potential of South African plants against Mycobacterium infections. J. Ethnopharmacol. 119, 482-500.

Mojeremane, W., and Tshwenyane, S. O. (2004). The resource role of Morula (Slerocarya birrea): a multipurpose indigenous fruit tree of Botswana. J. Biol. Sci. 4,771-775.

Mongelli,E., Desmarchelier,C., RodriguezTalou, J., Coussio, J., and Ciccia, G. (1997). In vitro antioxidant and cytotoxic activity of extracts of Baccharis coridifolia DC. J. Ethnopharmacol.58, 157-163.

Morré, D. J., De Cabo, R., Farley, C. Oberlies, N. H., and McLaughlin, J. L. (1995). Mode of action of bullatacin, a potent antitumor acetogenin: inhibition of NADH oxidase activity HeLa and HL-60 but not liver, plasma membranes. Life Sci. 56, 343-348.

Mosmann, T. (1983). Rapid colorimetric assay for cellular grow and survival application and cytotoxicity assays. J. Immunol. Methods 65, 55-63.

Moundipa, P. F., Beboyl, N. S. E., Zelefack, F., Ngouela, S., Tsamo, E., Schill, W.-B., and Monsees, T. K. (2005). Effects of Basella alba and Hibiscus macranthus extracts on testosterone production of adult rat and bull Leydig cells. Asian J. Androl. 7, 411-417.

Nana, P., Asongalem, E. A., Foyet, H. S., Folefoc, G. N., Dimo, T., and Kamtchouing, P. (2008). Maternal and developmental toxicity evaluation of Acanthus montanus leaves extract administered orally to Wistar pregnant rats during organogenesis. J. Ethnopharmacol. 116, 228-233.

Ndebia, E. J., Kamgang, R., and NkehChungagAnye, B. N. (2007). Analgesic and anti-inflammatory properties of aqueous extract from leaves of
Solanum torvum (solanaceae). Afr. I. Trad. CAM 4, 240-244.

Ndifossap, I. G. M., Frigerio, F., Casimir, M., Tsofack, F. N., Dongo, E., Kamtchouing, P., Dimo, T., and Maechler, P. (2010). Sclerocarya birrea (Anacardiaceae) stem-bark extract corrects glycaemia in diabetic rats and acts on b-cells by enhancing glucose-stimulated insulin secretion. J. Endocrinol. 205, 79-86.

Neuwinger, H. D. (1998). Afrikanische Arzneiplanzen und Jagdgifte. Stuttgart: Wissenschaftliche Verlasgesellschaft.

Newman, D. J., and Cragg, G. M. (2007). Natural products as sources of new drugs over the last 25 years. J. Nat. Prod. 70, 461-477.

Ngadjui, B. T., Dongo, E., Ayafor, J. F., and Connolly, J.D. (1994). Thomandertiol, a tetraterpenoid from the twigs of Thomandersia laurifolia. J. Nat. Prod. 57, 161-163.

Ngameni, B., Kuete, V., Simo, I. K., Mbaveng, A. T., Awoussong, P. K., Patnam, R., Roy, R., and Ngadjui, B. T. (2009). Antibacterial and antifungal activities of the crude extract and compounds from Dorstenia turbinata (Moraceae). S. Afr. J. Bot. 75, 256-261.

Ngameni, B., Touaibia, M., Belkaid, A., Ambassa, P., Watchueng, J., Patnama, R., Ngadjui, B. T., Annabi, B., and Roy, R. (2007). Inhibition of matrix metalloproteinase- 2 secretion by chalcones from the twigs of Dorstenia barteri bureau. Arkivoc 9, 91-103.

Ngameni, B., Touaibia, M., Patnam, R., Belkaid, A., Sonna, P., Ngadjui, B. T., Annabi, B., and Roy, R. (2006). Inhibition of MMP-2 secretion from brain tumor cells suggests chemopreventive properties of a furanocoumarin glycoside and of chalcones isolated from the twigs of Dorstenia turbinata. Phytochemistry 67, 2573-2579.

Ngantchou, I., Barthélemy Nyasse, B., Denier, C., Blonski, C., Hannaert, V., and Schneider, B. (2010). Antitrypanosomal alkaloids from Polyalthia suaveolens (Annonaceae): their effects on three selected glycolytic enzymes of Trypanosoma brucei. Bioorg. Med.Chem. Lett. 20, 3495-3498.

Ngemenya, M. N., Akam, T. M., Yong, J. N., Tane, P., Fanso-Free, S. N. Y., Berzins, K., and Titanji, V. P. K. (2006). Antiplasmodial activities of some products from Turreanthus africanus (Meliaceae). Afr. J. Health Sci. 13, 33-39.

Ngo Mpeck, M. L., Tchoundjeu, Z., and Asaah, E. (2004). The role of vegetative propagation in the domestication of Pausinystalia johimbe (K. Schum), a highly threatened medicinal species 
of West and Central Africa. Forest Ecol. Manag. 188, 175-183.

Ngondi, J., Oben, J., and Minka, S. (2005). The effects of Irvingia gabensis seeds on body weight and blood lipids of obese subject in Cameroon. Lipids Health Dis. 4, 12.

Ngouela, S., Lenta, B. N., Tchamo Noungoue, D., Ngoupayo, J., Boyom, F., Tsamo, E., Gut, J., Rosenthal, P. J., and Connolly, J. D. (2006). Antiplasmodial and antioxidant activities of constituents of the seed shells of Symphonia globulifera Linn $\mathrm{f}$. Phytochemistry 67, 302-306.

Ngounou, E. N., Meli, A. L., and Lontsi, D. (2000). New isoflavone from Ceiba pendandra. Phytochemistry 54, 107-110.

Nguemfo, E. L., Dimo, T., Azebaze,A. G. B., Asongalem, E. A., Alaoui, K., Dongmo, A. B., Cherrah, Y., and Kamtchouing, P. (2007). Anti-inflammatory and anti-nociceptive activities of the stem bark extracts from Allanblackia monticola Staner LC (Guttiferae). J. Ethnopharmacol. 114, 417-424.

Nguemfo, E. L., Dimo, T., Dongmo, A. B., Azebaze, A. G. B., Alaoui, K., Asongalem, A. E., Cherrah, Y., and Kamtchouing, P. (2009). Antioxidative and anti-inflammatory activities of some isolated constituents from the stem bark of Allanblackia monticola Staner L.C (Guttiferae). Inflammopharmacology 17, 37-41.

Nishimura, R., Tabata, K., Arakawa, M., Ito, Y., Kimura, Y., Akihisa, T., Nagai, H., Sakuma, A., Kohno, H., and Suzuki, T. (2007). Isobavachalcone, a chalcone constituent of Angelica keiskei, induces apoptosis in neuroblastoma. Biol. Pharm. Bull. 30, 1878-1883.

Njamen, D., Mbafor, J. T., Fomum, Z. T., Kamanyi, A., Mbanya, J. C., Recio, M. C., Giner, R. M., Manez, S., and Rios, J. L. (2004). Anti-inflammatory activities of two flavanones, sigmoidin A and sigmoidin B, from Erithrina sigmoidea. Planta Med. 70, 104-107.

Njamen, D., Talla, E., Mbafor, J. T., Fomum, Z. T., Kamanyi, A., Mbanya, J. C., Cerda-Nicolas, M., Giner, R. M., Recio, M. C., and Rios, J. L. (2003). Anti-inflammatory activity of erycristagallin, a pterocarpene from Erythrina mildbraedii. Eur. J. Pharmacol. 468, 67-74.

Njike, G. N., Watcho, P., Nguelefack, T. B., and Kamanyi, A. (2005). Hypoglycaemic activity of the leaves extracts of Bersama engleriana in rats. Afr. J. Trad. CAM 2, 215-221.

Nkeh-Chungag, B. N., Temdie, J. R., Sewani-Rusike, C., Fodjo, Y. M., Mbafor, J. T., and Iputo, J. E. (2009). Analgesic, anti-inflammatory and antiulcer properties of the extract of Uapaca guineensis (Euphorbiaceae).J. Med. Plants Res. 3, 635-640.
Nkengfack, A., Azebaze, A. G. B., Waffo, A. K., Fomum, Z. T., Meyer, M., and Van Heerden, F. R. (2001). Cytotoxic isoflavones from Erythrina indica. Phytochemistry 58, 1113-1120.

Nkengfack, A. E., Mkounga, P., Fomum, Z. T., Meyer, M., and Bodo, B. (2002). Globulixanthones A and B, two new cytotoxic xanthones with isoprenoid groups from the root bark of Symphonia globulifera. J. Nat. Prod. 65, 734-736

Nkongmeneck, B. A., Mapongmetsem, P. M., Pinta, Y.V., Nkuinkeu, R., Tsabang, N., Fongnzossie, E., Kemeuze, V., Jiofack, T., Johnson, M., Asaha, S., Sakwe, C., and Mboufack, C. (2007). Etat des lieux des plantes médicinales importantes à conserver et des jardins de plantes médicinales à promouvoir. Geneva: Rapport CEN/OMS/MEM.

Noeske, J., Kuaban, C., and Cunin, P. (2004). Are smear-positive pulmonary tuberculosis patients a "sentinel" population for the HIV epidemic in Cameroon? Int. J. Tuberc. Lung Dis. 8, 346-351.

Noumi, E., and Dibakto, T. W. (2000) Medicinal plants used for peptic ulcer in the Bangangté region, Western Cameroon. Fitoterapia 70, 406-412.

Noumi, E., and Dibakto, T. W. (2002) Medicinal plants used for peptic ulcer in the Bangangte region, western Cameroon. Fitoterapia 71, 406-512.

Noumi, E., and Fozi, F. L. (2003) Ethnomedical botany of epilepsy treatment in Fongo-Tongo village, Werstern province, Cameroon. Pharm. Biol. 41, 330-339.

Noumi, E., Houngue, F., and Lontsi, D. (1999).Traditional medicines in primary health care: plants used for the treatment of hypertension in Bafia, Cameroon. Fitoterapia 70, 234-239.

Noumi, E., and Tchakonang, N. Y. C. (2001). Plants used as abortificients in the Sangmelima region of Southern Cameroon. J. Ethnopharmacol. 76, 263-268.

Nowakowska, Z. (2007). A review of anti-infective and anti-inflammatory chalcones. Eur. J. Med. Chem. 42 , 125-137.

Nyemba, A. M., Ngando, M. T., Connolly, J. D., and Rycroft, D. S. (1990). Cycloartane derivatives from Garcinia lucida. Phytochemistry 29, 994-998.

Nyunaï, N., Njikam, N., Abdennebi, E. H., Mbafor, J. T., and Lamnaouer, D. (2009). Hypoglycaemic and antihyperglycaemic activity of Ageratum conyzoides L. in rats. Afr. J. Trad. CAM 6, 123-130.

Nzowa, L. K., Barboni, L., Teponno, R. B., Ricciutelli, M., Lupidi, G., Quassinti, L., Bramucci, M., and Tapondjou, A. L. (2010). Rheediinosides A and
B, two antiproliferative and antioxidant triterpene saponins from Entada rheedii. Phytochemistry 71 254-261.

Obih, P. O., Makinde, J. M., and Laoye, J. (1985). Investigation of various extracts of Morinda lucida for antimalarial actions on Plasmodium berghei in mice. Afr. J. Med. Sci. 14 45-49.

Ojewole, J. A. (2003). Hypoglycemic effect of Sclerocarya birrea [(A. Rich.) Hochst.] [Anacardiaceae] stem-bark aqueous extract in rats. Phytomedicine $10,675-681$.

Ojewole, J. A. O. (2004). Evaluation of the analgesic, anti-inflammatory and anti-diabetic properties of Sclerocarya birrea (A. Rich.)Hochst. stem-bark aqueous extract in mice and rats. Phytother. Res 18, 601-608.

Oliver-Bever, B. (1986). Medicinal Plants in Tropical West Africa. New York, NY USA: Cambridge University Press.

Omisore, N. O. A., Adewunmi, C. O., Iwalewa, E. O., Ngadjui, B. T., Adenowo, T. K., Abegaz, B. M., Ojewole, J. A., and Watchueng, J. (2005). Antitrichomonal and antioxidant activities of Dorstenia barteri and Dorstenia convexa. Braz. J. Med. Biol. Res. 38, 1087-1094.

Onunkwo, G. C., Akah, P. A., and Udeala, O. K. (1996). Studies on B. Ferruginea leaves. (I). Stability and hypoglycemic actions of the leaf extract tablets. Phytother. Res 10, 418-420.

Osadebe, P. O., and Okoye, F. B. C. (2003). Anti-inflammatory effects of crude methanolic extract and fractions of Alchornea cordifolia leaves. $J$. Ethnopharmacol. 89, 19-24.

Ouellette, M., Drummelsmith, J. and Papadopoulou, B. (2004) Leishmaniasis: drugs in the clinic, resistance and new developments. Drug Resist. Updates 7, 257-266.

Pham-Huy, L.A., He, H., and Pham-Huyc, C. (2008). Free radicals, antioxidants in disease and health. Int. J. Biomed. Sci 2, 89-96.

Pieme, C. A., Penlap, V. N., Ngogang, J., and Costache, M. (2010). In vitro cytotoxicity and antioxidant activities of five medicinal plants of Malvaceae family from Cameroon. Environ. Toxicol. Pharmacol. 29, 223-228.

Ponou, B. K., Luciano Barboni, L., Teponno, R. B., Mbiantcha, M. Nguelefack, T. B., Park, H. J., Lee, K. T., and Tapondjou, A. L. (2008) Polyhydroxyoleanane-type triterpenoids from Combretum molle and their anti-inflammatory activity. Phytochem. Lett. 1, 183-187.

Prajapati, N.D., Purohit, S. S., and Kumar, T. (2003). A Handbook of Medicinal Plants. Agrobios, India: A Complete Source Book.
Raponda-Waker,A., and Sillans, R. (1961). Les plantes utiles du Gabon. Paris: Paul Lechevalier.

Raza, M., Shaheen, F., Choudhary, M. I., Suria, A., Rahman, U. A., Sompong, S., and Delorenzo, R. J. (2001). Anticonvulsant activities of the FS-1 subfraction isolated from roots of Delphinium denudatum. Phytother Res. 15, 426-430.

Ringwald, P., Bickii, J., and Basco, L. K. (1996). In vitro activity of antimalarials against clinical isolates of Plasmodium falciparum in Yaoundé, Cameroon. Am. J. Trop. Med. Hyg. 55, 254-258.

Sandberg, F., and Cronlund, A. (1977). "What can we still learn from traditional folklore medicine? Examples from the results of a biological screening of medicinal plants from Equatorial Africa," Proceeding of Third Symposium Medical Plants and Spices, Colombo, Sri Lanka, February 6-12.

Sokeng, S. D., Rokeya, B., Mostafa, M., Nahar, N., Mosihuzzaman, M., Ali, L., and Kamtchouing, P. (2005). Antihyperglycemic effect of Bridelia ndellensis ethanol extract and fractions in streptozotocin-induced diabetic rats. Afr. J. Trad. CAM 2 , 94-102.

Sokeng, S. D., Lontsi, D., Moundipa, P. F., Jatsa, H. B., Watcho, P., and Kamtchouing,P. (2007).Hypoglycemic effect of Anacardium occidentale $\mathrm{L}$. methanol extract and fractions on streptozotocin-induced diabetic rats. Res. J. Med. Med. Sci. 2, 133-137.

Speak Clear Association of Cameroon. (2004). Facts About Cameroon. http:// www.stutterisa.org/cameroon/scacl html. (Accessed on May 03, 2010).

Stévigny, C., Bailly, C., and QuetinLeclercq, J. (2005). Cytotoxic and antitumor potentialities of aporphinoid alkaloids. Curr. Med. Chem. AntiCancer Agents 5, 173-182.

Surville, N. (1955). Notes Sur Quelques Plantes Médicinales du Sud Cameroun. Paris: ORSTOM-IRC.

Szeltner, Z., Renner, V., and Polgar, L. (2000). Substrate- and $\mathrm{pH}$-dependent contribution of oxyanion binding site of the catalysis of prolyloligopeptidase, a paradigm of serine oligopeptidase family. Protein Sci. 9, 353-360.

Tabopda, T. K., Ngoupayo, J., Liu, J., Mitaine-Offer, A. C., Tanoli, S. A., Khan, S. N., Ali, M. S., Ngadjui, B. T., Tsamo, T., Lacaille-Dubois, M. A., and Luu, B. (2008). Bioactive aristolactams from Piper umbellatum. Phytochemistry 69, 1726-1731.

Talla, E., Njamen, D., Mbafor, J. T., Fomum, Z. T., Kamanyi, A., Mbanya, J.C., Giner, R. M., Recio, M. C., Máñez, S., and Rios, J. (2003). Warangalone, 
the isoflavonoid anti-inflammatory principle of Erythrina addisoniae Stem Bark. J. Nat. Prod. 66, 891-893.

Tangmouo, J. G., Raimana Ho, R., Lannang, A. L., Komguem, J., Lontsi, T. A., Lontsi, D., and Hostettmann, K. (2009). Norbergenin derivatives from the stem bark of Diospyros sanzaminika (Ebenaceae) and their radical scavenging activity. Phytochem. Lett. 2, 192-195.

Tchinda, A. T., Tsopmo,A., Tane, P., Ayafor,J. F.,Connolly,J.D., and Sterner, O. (2002). Vernoguinosterol and vernoguinoside, trypanocidal stigmastane derivatives from Vernonia guineensis (Asteraceae). Phytochemistry 59, 371-374.

Tchuendem,M.H.K.,Mbah,J.A., Tsopmo, A.,Ayafor,J.F.,Sterner, O.,Okunjic, C.C., Iwu, M. M., and Schuster, B. M. (1999). Anti-plasmodial sesquiterpenoids from the African Reneilmia cincinnata. Phytochemistry 52, 1095-1099.

Telefo, P. B., Moundipa, P. F., Tchana, A. N., Dzickotze, C. T., and Mbiapo, F. T. (1998). Effects of an aqueous extract of Aloe buettneri, Justicia insularis, Hibiscus macranthus, Dicliptera verticillata on some physiological and biochemical parameters of reproduction in immature female rats. $J$. Ethnopharmacol. 63, 193-200.

Terao, J., and Piskula, M. K. (1997). "Flavonoids as inhibitors of lipid peroxidation in membranes," in Flavonoids in Health and Disease, eds C.A. Rice-Evans and L. Packer (New York: Marcel Dekker), 277-295.

Théophile, D., Laure, E. N., Benoît, N. T., Anatole, A. G. B., Emmanuel, A. A., Paul, T. V., and Pierre, K. (2006). Antinociceptive and antiinflammatory effects of the ethyl acetate stem bark extract of Bridelia scleroneura (Euphorbiaceae). Inflammopharmacology 14, 42-47.

Titanji, V.P.K., Zofou, D., and Ngemenya, M.N. (2008). The antimalarial potential of medicinal plants use and for the treatment of malaria in Cameroonian folk medicine. Afr. J. Trad. CAM 5, 302-321.
Tsabang, N., Nkongmeneck, B. A., Zapfack, L., Dongmo, Z., Nguenang, G. M., Lando, G., Carlson, T. J., and Lowry, II. P.P. (2001). Inventaire des plantes à vertus antidiabétiques dans la région de Yaoundé au Cameroun. Rev. Med. Pharmacop. Afr 15, 87-94.

Tsopmo, A., Tene, M., Kamnaing, P., Ayafor, J. F., and Sterner, A. (1999). A new Diels-Alder type adduct flavonoids from D. barteri. J. Nat. Prod. 62, 1432-1434.

Ueda, H., Kaneda, N., and Kawanishi, K. (2002). A new isoflavone glycoside from Ceiba pentandra (L.). Gaertner. Chem. Pharm. Bull. 50, 403-404.

Vardamides, J. C., El Alaoui, H., Massoma, D. L., Azebaze, A. G. B., Ndemangou, B., Sielinou, V.T., Meyer, M., Vivares, C. P., Fomum, Z. T., and Nkengfack, A. E. (2008).Anticoccidial constituents from the stem bark of Turraeanthus africanus. Chem. Nat. Comp. 44, 696-700.

Vivien, J., and Faure, J. J. (1996). Frutiers sauvagesd'Afrique: Especes du Cameroon Nguila-Kerou. Paris: Lavoisier.

Voss, C., Eyol, E., and Berger, M. R. (2005). Identification of potent anticancer activity in Ximenia Americana aqueous extracts used by African traditional medicine. Toxicol. Appl. Pharmacol 211, 177-187.

Waffo, A. F. K., Mulholland, D., Wansi, J. D., Mbaze, L. M., Powo, R., Mpondo, T. N., Fomum, Z. T., König, W., and Nkengfack, A. E. (2006). Afzeliixanthones A and B, two new prenylated xanthones from Garcinia afzelii Engl. (Guttiferae). Chem. Pharm. Bull. 54, 448-451.

Walgate, R. (2008). Diabetes research for developing countries. N. Biotechnol. 25, 111-116.

Wang, H., Nair, M. G., Strasburg, G. M., Chen-Chang, Y., Booren, A. M., Gray, I. J., and DeWitt, D. L. (1999). Antioxidant and anti-inflammatory activities of anthocyanins and their aglycone, cyaniding from Tart Cherries. J. Nat. Prod. 62, 294-296.

Watcho, P., Kamtchouing, P., Sokeng, S., Moundipa, P. F., Tantchou, J.,
Essame, J. L., and Koueta, N. (2001). Reversible antispermatogenic and antifertility activities of Mondia whitei L. in male albino rat. Phytother. Res. 15, 26-29.

Watcho, P., Makemdjio, A., Nguelefack, B. T., and Kamanyi, A. (2007). Sexual stimulation effects of the aqueous and methanolic extracts from the leaves of Bersama engleriana in adult male rats. Pharmacol. Online 1, 464-476.

Watt, J. M., and Breyer-Brandwijk, M. G. (1962). The Medicinal and Poisonous Plants of Southern and Eastern Africa. Edinburgh: Livingstone, E.S.

Weenen, H., Nkunya, M. H. H., Bray, D. H., Mwasumbi, L. B., Kinabo, L. S., and Kilimali, V.A.E.B. (1990). Antimalarial activity of Tanzanian medicinal plants. Planta Med. 56, 368-370.

Whelan, L. C., and Ryan, M. F. (2003). Ethanolic extracts of Euphorbia and other ethnobotanical species as inhibitors of human tumour cell growth. Phytomedicine 10, 53-58.

WHO. (1980). WHO Expert committee on diabetes mellitus: second report. Tech. Rep. Ser 646, 1-80.

WHO. (1985). Diabetes mellitus: report of a WHO study group. Tech. Rep. Ser. 727, 1-113.

WHO. (2002). WHO traditional medicine strategy 2002-2005. Geneva. http://whqlibdoc.who.int/hq/2002/ WHO_EDM_TRM_2002.1.pdf.2002. (Accessed on January 13, 2008).

WHO. (2005). Leishmaniasis: background information. http://www.who.int/ leishmaniasis/en/. (Accessed on May 08, 2010).

WHO. (2007). African Trypansosomiasis (sleeping sickness). WHO fact sheet no. 259; World Health Organization: Geneva, Switzerland, 2001 (updated August 2007); http://www.who.int/ mediacentre/factsheets/fs259/en/. (Accessed on May 08, 2010).

WHO. (2009). World health statistics 2009: Cause-specific mortality and morbidity. http://www.who.int/whosis/whostat/EN_WHS09_Table2.pdf. (Accessed on May 03, 2010).
Willcox, M., Bodeker, G., and Rasanavo, P. (2004a). Traditional Medicinal Plants and Malaria. Paris: CRC Press.

Willcox, J. K., Ash, S. L., and Catignani, G. L. (2004b). Antioxidants and prevention of chronic disease. Crit. Rev. Food. Sci. Nutr. 44,275-295.

Yankep, E., Njamen, D., Fotsing, M. T., Fomum, Z. T., Mbanya, J. C., Giner, R. M., Carmen Recio, M., Manez, S., and Rios, J. L. (2003). Griffonianone $\mathrm{D}$, an isoflavone with anti-inflammatory activity from the root bark of Millettia griffoniana. J. Nat. Prod. 66, 1288-1290.

Youns, M., Hoheisel, J. D., and Efferth, T. (2010). Traditional Chinese medicine (TCMs) for molecular targeted therapies of tumors. Curr. Drug. Discov. Technol. 7, 37-45.

Zhou, B., Baj, N. J., Glass, T. E., Malone, S., Werkhoven, M. C. M., van Troon, F, Jan, D., Wisse, H., and Kingston, D. G. I. (1997). Bioactive labdane diterpenoid from Renealmiaalpinia (Zingiberaceae) collected from Suriname rainforest. $J$. Nat. Prod. 60, 1287-1293.

Conflict of Interest Statement: The authors declare that the research was conducted in the absence of any commercial or financial relationships that could be construed as a potential conflict of interest.

Received: 30 June 2010; paperpending published: 30 July 2010; accepted: 07 September 2010; published online: 25 October 2010.

This article was submitted to Frontiers in Ethnopharmacology, a specialty of Frontiers in Pharmacology.

Citation: Kuete V and Efferth T (2010) Cameroonian medicinal plants: pharmacology and derived natural products. Front. Pharmacol. 1:123. doi: 10.3389/ fphar.2010.00123

Copyright $\odot 2010$ Kuete and Efferth. This is an open-access article subject to an exclusive license agreement between the authors and the Frontiers Research Foundation, which permits unrestricted use, distribution, and reproduction in any medium, provided the original authors and source are credited. 